N evada

Environmental

Restoration

Project

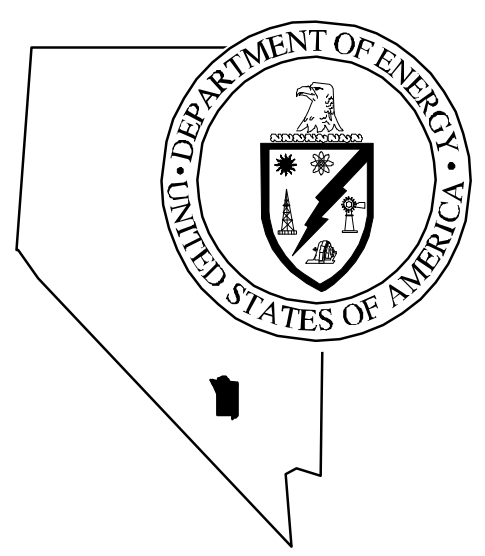

Corrective Action Investigation Plan for Corrective Action Unit 263 : Area 25 Building 4839 Leachfield, $\mathrm{N}$ evada Test $\mathrm{Site}, \mathrm{N}$ evada

Controlled Copy N $0 .:$

Revision N 0.: 0

March 1999

Approved for public release; further dissemination unlimited.

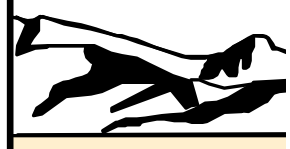

Environm ental Restoration

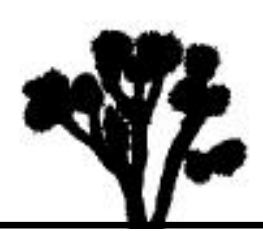

Division 
Available to the public from -

U.S. Department of Commerce

National Technical Information Service

5285 Port Royal Road

Springfield, VA 22161

(703) 487-4650

Available electronically at http://www.doe.gov/bridge. Available to U.S. Department of Energy and its contractors in paper from -

U.S. Department of Energy

Office of Scientific and Technical Information

P.O. Box 62

Oak Ridge, TN 37831-0062

(423) 576-8401

Reference herein to any specific commercial product, process, or service by trade name, trademark, manufacturer, or otherwise, does not necessarily constitute or imply its endorsement, recommendation, or favoring by the United States Government or any agency thereof or its contractors or subcontractors 


\title{
CORRECTIVE ACTION INVESTIGATION PLAN FOR CORRECTIVE ACTION UNIT 263: AREA 25 BUILDING 4839 LEACHFIELD, NEVADA TEST SITE, NEVADA
}

\author{
DOE Nevada Operations Office \\ Las Vegas, Nevada
}

Controlled Copy No.:

Revision No.: 0

March 1999

Approved for public release; further dissemination unlimited. 


\section{CORRECTIVE ACTION INVESTIGATION PLAN \\ FOR CORRECTIVE ACTION UNIT 263: \\ AREA 25 BUILDING 4839 LEACHFIELD, NEVADA TEST SITE, NEVADA}

Signature Approved

Approved by:

Date:

Janet Appenzeller-Wing, Project Manager

Industrial Sites Project

Signature Approved

Approved by:

Date:

Runore C. Wycoff, Division Director

Environmental Restoration Division 


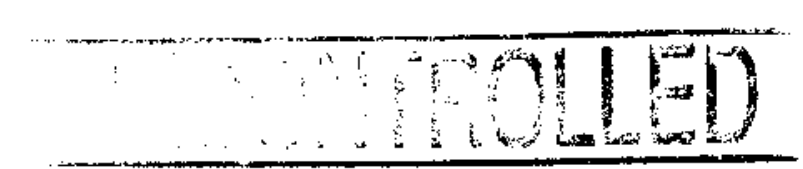

RECORD OF TECHNICAL CHANGE

Technical Change No.: 1 Page 1 of 2 Project/Job No: $\quad \mathbf{7 7 6 7 1 1 . 2 9 0 2 0 1 0 0}$

Date April 12, 1999

Project/Job Name: Industrial Sites/ CAU 263 Area 25 Building 4839 Leachfield

The following technical changes (including justification) are requested by:

Candice M. Fillmore

(Name)
Engineer/Scientist I

(Title)

The technical changes specified in this Record of Technical Change apply to the Executive Summary and Sections 1.2, 2.5, 3.2, 3.3, 4.1, 4.2.1.2, 4.2.1.4, of the Corrective Action Investigation Plan for Corrective Action Unit 263: Area 25 Building 4839 Leachfield, Nevada Test Site, Nevada, Revision 0, DOE/NV--535. The additions and changes are necessary because past work experience in Area 25 indicated that radioactive contamination was possible. While no process information was identified that would indicate radionuclides were disposed to this leachfield, analysis for radionuclides using gamma spectrometry is being included as a precautionary measure to support the site investigation and waste management activities.

Executive Summary, Page ES-2 of ES-3, paragraph 1, bullet one

Change the fifth dash to read as follows:

Conduct laboratory analysis of environmental samples for total volatile organic compounds and semivolatile organic compounds. Gamma spectrometry analysis will be performed for all samples with radiological field-screening results exceeding field-screening levels. A minimum of 25 percent of the samples will be submitted for gamma spectrometry analysis as a precautionary measure.

Section 1.2, bullet one

Change the fourth dash to read as follows:

Collect environmental samples for laboratory analysis of semivolatile organic compounds (SVOCs) and total volatile organic compounds (VOCs). Analysis for radiological contaminants will be conducted for all samples with field-screening results exceeding field-screening levels. A minimum of 25 percent of the samples will be submitted for gamma spectrometry analysis as a precautionary measure.

Section 3.2, bullet three

Change to read as follows:

Gamma spectrometry analysis for all samples with field-screening results exceeding field-screening levels. A minimum of twenty-five percent of the samples will be analyzed by gamma spectrometry, irrelevant of field-screening results, as a precautionary measure. 


\section{RECORD OF TECHNICAL CHANGE}

Technical Change No:

Page 2 of 2

Date April 12,1999

Section 4.1, bullet one

Change the fifth dash to read as follows:

Conduct laboratory analysis of environmental samples for total VOCs and SVOCs. Analysis of radiological contaminants will be conducted if field screening results exceed field-screening levels. A minimum of 25 percent of the samples will be analyzed by gamma spectrometry, irrelevant of field screening results.

\section{Section 4.2.1.2, paragraph three}

Change the sixth sentence to read as follows:

The third portion will be retained for radiological components.

\section{Section 4.2.1.4, bullet three}

Change to read as follows:

Gamma spectrometry analysis for all samples with field-screening results exceeding field-screening levels. A minimum of twenty-five percent of the samples will be analyzed by gamma spectrometry, irrelevant of field-screening results, as a precautionary measure.

\footnotetext{
The project time will be (Increased) (Decreased) (Unchanged) $\mathrm{X} \quad$ by approximately_ 0 _days

Applicable Project-Specific Document(s):

Corrective Action Investigation Plan for Corrective Action Unit 263: Area 25 Building 4839 Leachfields, Nevada Test Site, Nevada, Revision 0, DOE/NV--535.
}

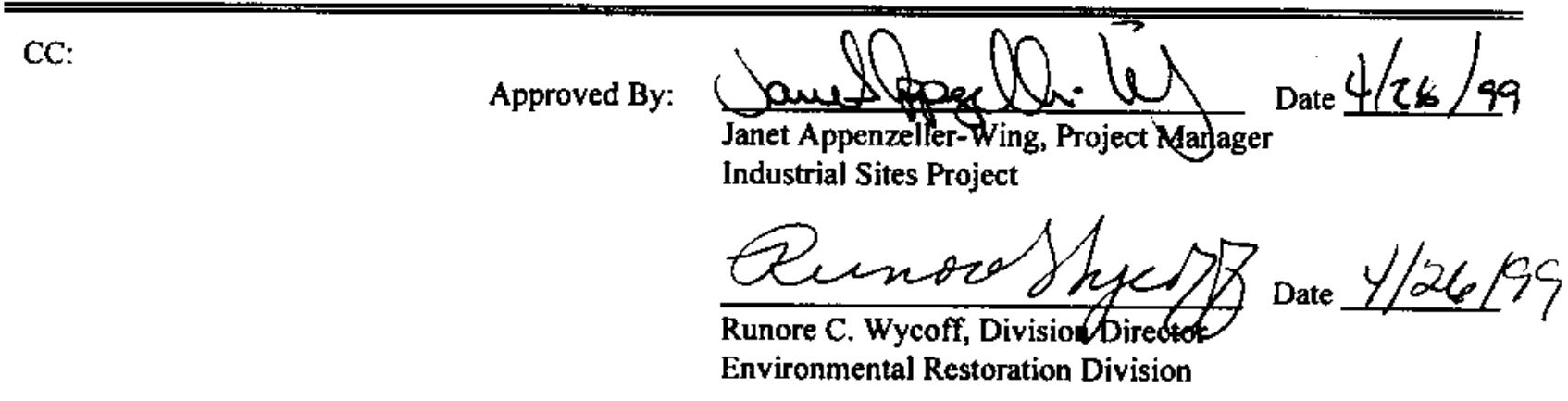

Environmental Restoration Division 


\section{Table of Contents}

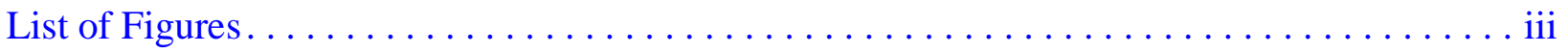

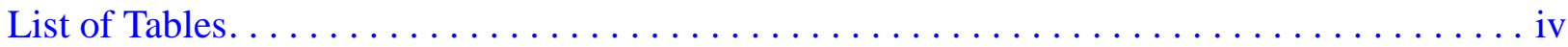

List of Acronyms and Abbreviations ............................... v

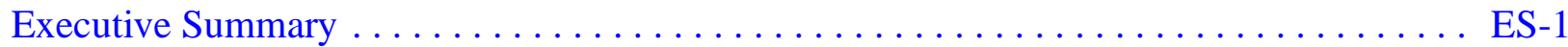

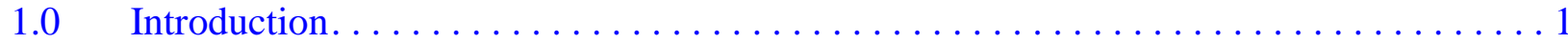

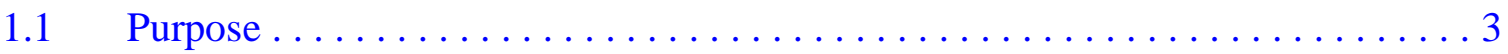

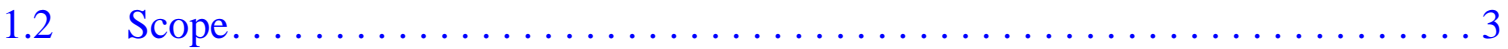

$1.3 \quad$ CAIP Contents ..................................... 4

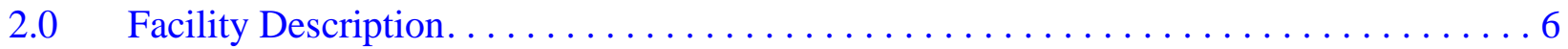

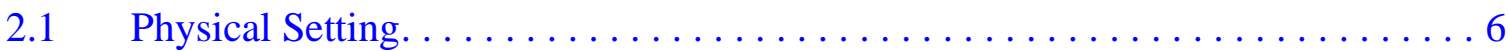

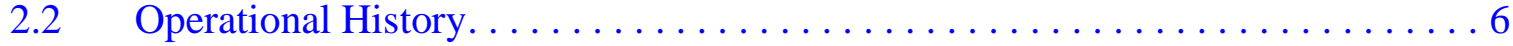

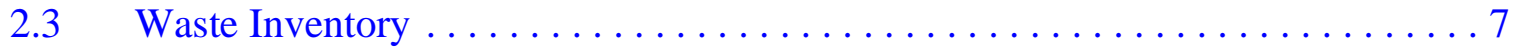

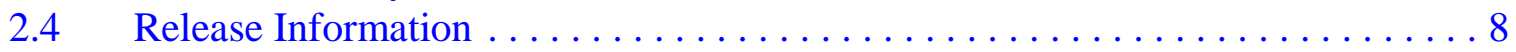

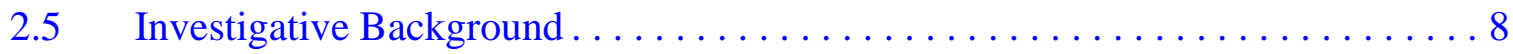

$3.0 \quad$ Objectives .......................................... 11

$3.1 \quad$ Conceptual Site Model ................................ 11

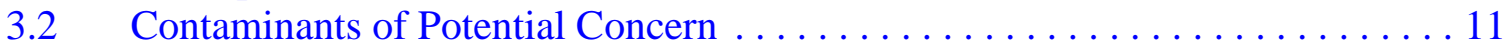

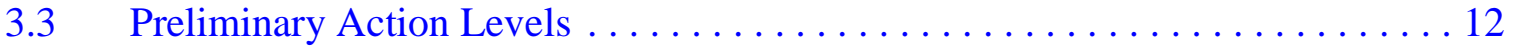

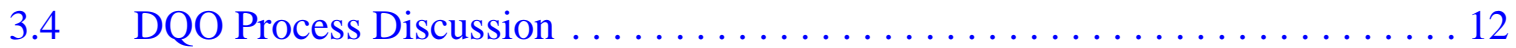

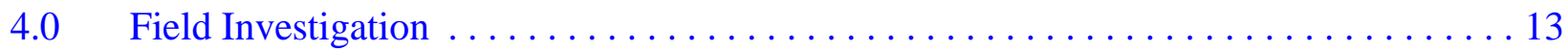

$4.1 \quad$ Technical Approach . . . . . . . . . . . . . . . . . . . . . . . . . . 13

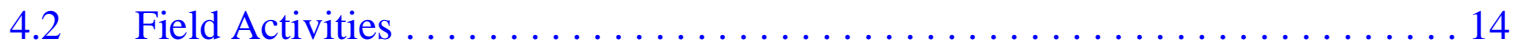

4.2.1 Stage One Activities ............................ 15

4.2.1.1 Sampling of Septic Tank .................... 15

4.2.1.2 Direct-Push Method .......................... 15

4.2.1.3 Field Screening Method $\ldots \ldots \ldots \ldots \ldots \ldots \ldots \ldots \ldots$

4.2.1.4 Laboratory Analysis $\ldots \ldots \ldots \ldots \ldots \ldots \ldots \ldots \ldots$

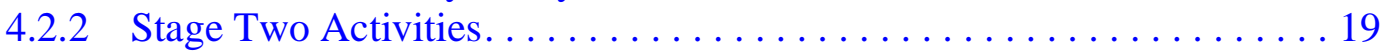

4.2.2.1 Video Survey ............................. 19

4.2.2.2 Excavation and Trenching Activities $\ldots \ldots \ldots \ldots \ldots \ldots .20$

4.2.2.3 Step-Out Direct Push Methods $\ldots \ldots \ldots \ldots \ldots \ldots \ldots \ldots \ldots$

$5.0 \quad$ Waste Management. . . . . . . . . . . . . . . . . . . . . . . . . . 22

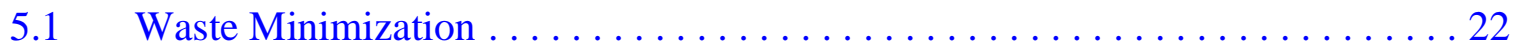




\section{Table of Contents (Continued)}

5.2 Potential Waste Streams . . . . . . . . . . . . . . . . . . . 22

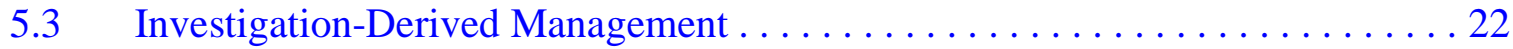

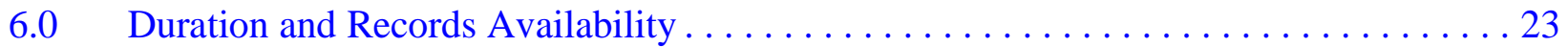

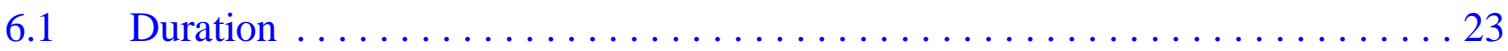

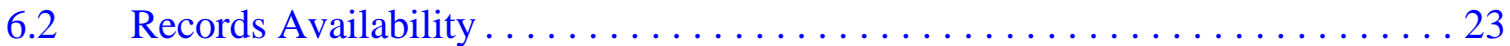

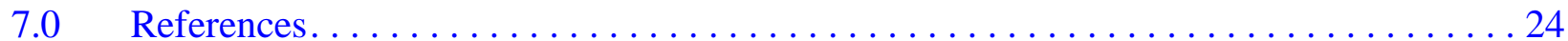

\section{Appendix A - Data Quality Objectives Worksheets}

A.1.0 Introduction. . . . . . . . . . . . .

A.1.1 Problem Statement . . . . . . . . . . . . . . . . . . . . . . . . . . . A-1

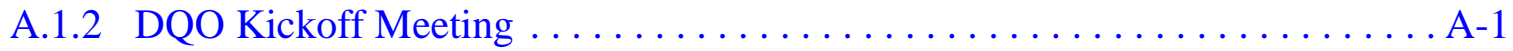

A.2.0 Conceptual Model. . . . . . . . . . . . . . . . . . . . . . . . . . A-3

A.3.0 Potential Contaminants . . . . . . . . . . . . . . . . . . . . . . . . . . . . . . A-5

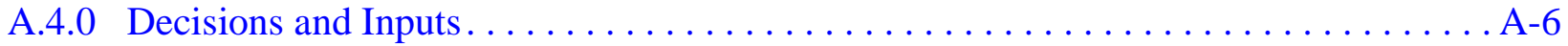

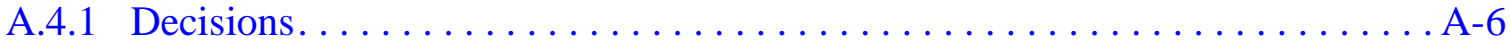

A.5.0 Investigation Strategy . . . . . . . . . . . . . . . . . . . .

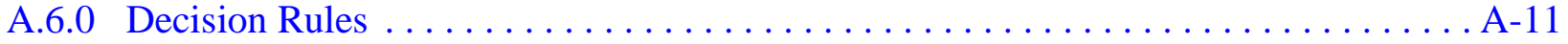

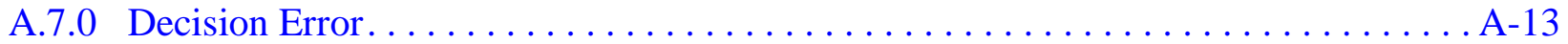

A.8.0 References........ . . . . . . . . . . . . . . . . . . . . . . . . . . . . . . A-14

Appendix B - Project Organization

B.1.0 Project Management . . . . . . . . . . . . . . . . . . . . . . . .

Appendix C - Engineering Drawings of CAU 263

Appendix D - NDEP Comment Review Sheets 


\section{List of Figures}

Number

1-1 CAU 263 Area 25 Building 4839 Sewer Drainage and Outfalls Nye County, Nevada . . . . . . . . . . . . . . . . . . . . . . . . . 2

4-1 CAU 263 Proposed Sampling Locations. . . . . . . . . . . . . . . . 16

A.5-1 CAU 263 Proposed Sampling Locations. . . . . . . . . . . . . . . A-10

C-1 Existing Water \& Sewer Layout Central Support Area Plan . . . . . . . . . . . . C-1

C-2 Central Propellant Area Installation of Trailer \#42 (Sewer Line) . . . . . . . . . C-2

C-3 Central Propellant Area Office and Shop Facility Mechanical Plans

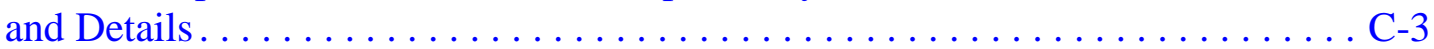

C-4 Central Propellant Area Office and Shop Facility Grading and Location Plans . . . . . . . . . . . . . . . . . . . . . . . . . . C-4 


\section{List of Tables}

Number

2-1 Preliminary Septic Tank Sampling Results.................. 9

A.1-1 DQO Kickoff Meeting Participants. ..................... A-2

A.2-1 Conceptual Model for the CAU 263 Leachfield System. . . . . . . . . . . . . . A-4

A.4-1 Decisions, Inputs, and General Strategies . . . . . . . . . . . . . . . A-7

A.6-1 CAS-Specific Decision Points and Rules . . . . . . . . . . . . . . A-12 


\section{List of Acronyms and Abbreviations}

bgs Below ground surface

BN Bechtel Nevada

CADD Corrective Action Decision Document

CAIP Corrective Action Investigation Plan

CAS Corrective Action Site(s)

CAU Corrective Action Unit(s)

$\mathrm{cm} \quad$ Centimeter(s)

COPC Contaminant(s) of potential concern

CPSA Central Propellant Storage Area

DOE U.S. Department of Energy

DOE/NV U.S. Department of Energy, Nevada Operations Office

DOT U.S. Department of Transportation

DQO Data Quality Objective(s)

ERD Environmental Restoration Division

FFACO Federal Facility Agreement and Consent Order

ft $\quad$ Foot (feet)

IDW Investigation-derived waste

IT IT Corporation

in. $\operatorname{Inch}(\mathrm{es})$

m Meter(s)

$\mathrm{mg} / \mathrm{kg} \quad$ Milligram(s) per kilogram

$\mathrm{mg} / \mathrm{L} \quad$ Milligram(s) per liter

NEPA National Environmental Policy Act

NDEP Nevada Division of Environmental Protection

NRDS Nuclear Rocket Development Station

NTS Nevada Test Site 


\section{List of Acronyms and Abbreviations (Continued)}

PAL Preliminary action level(s)

PID Photoionization detector

PRG Preliminary Remediation Goal(s)

QAPP Quality Assurance Project Plan

QA/QC Quality assurance/quality control

RCRA Resource Conservation and Recovery Act

SVOC Semivolatile organic compound(s)

VOC Volatile organic compound(s)

ug/kg Microgram(s) per kilogram 


\section{Executive Summary}

The Corrective Action Investigation Plan for Corrective Action Unit 263, the Area 25 Building 4839 Leachfield, has been developed in accordance with the Federal Facility Agreement and Consent Order that was agreed to by the U.S. Department of Energy, Nevada Operations Office; the Nevada Division of Environmental Protection; and the U.S. Department of Defense. Corrective Action Unit 263 is comprised of the Corrective Action Site 25-05-04 sanitary leachfield and associated collection system.

This Corrective Action Investigation Plan is used in combination with the Work Plan for Leachfield Corrective Action Units: Nevada Test Site and Tonopah Test Range, Nevada (DOE/NV, 1998d). The Leachfield Work Plan was developed to streamline investigations at Leachfield Corrective Action Units by incorporating management, technical, quality assurance, health and safety, public involvement, field sampling, and waste management information common to a set of Corrective Action Units with similar site histories and characteristics into a single document that can be referenced. This Corrective Action Investigation Plan provides investigative details specific to Corrective Action Unit 263.

Corrective Action Unit 263 is located southwest of Building 4839, in the Central Propellant Storage Area. Operations in Building 4839 from 1968 to 1996 resulted in effluent releases to the leachfield and associated collection system. In general, effluent released to the leachfield consisted of sanitary wastewater from a toilet, urinal, lavatory, and drinking fountain located within Building 4839 . The subsurface soils in the vicinity of the collection system and leachfield may have been impacted by effluent containing contaminants of potential concern generated by support activities associated with the Building 4839 operations.

Based on the site history collected to support the Data Quality Objectives process, contaminants of potential concern include volatile and semivolatile organic compounds. A conceptual site model for the Corrective Action Unit was developed as follows:

- Sanitary effluent potentially containing contaminants generated by personnel working at Building 4839 may have impacted subsurface soil in the vicinity of the collection system and leachfield. 
- Lateral extent of contaminants of potential concern is limited to the proximity of the site elements.

- Vertical extent of contaminants of potential concern is unknown, but probably limited because there are no release mechanisms and precipitation rates are low.

- Depth to groundwater is approximately 319 meters (1,047 feet); groundwater impacts are not expected.

- Future use of the site, as stated in the Final Environmental Impact Statement for the Nevada Test Site and Off-Site Locations in the State of Nevada (DOE/NV, 1996a), is assumed to be for research, testing, and experimentation.

- Potential exposure pathways are limited to ingestion, inhalation, and dermal contact.

The technical approach for investigating this Corrective Action Unit may involve a two stage process. The methods employed during Stage One activities are expected to be sufficient to confirm the theories presented in the conceptual site model. Stage Two methods will be employed if Stage One activities do not provide adequate investigation of the site. Descriptions of the two methods are as follows:

- Stage One:

- Collect samples from within the septic tank (this was done previously to support the Data Quality Objectives process).

- Collect subsurface samples from both ends of the septic tank and various locations within the leachfield boundaries using a direct-push method. Should direct-push not prove to be a viable method due to the composition of leachrock material, Stage Two trenching methods will be used.

- Collect background samples from a nearby undisturbed location using a direct-push method.

- Conduct field screening for volatile organic compounds using a headspace method (photoionization detector and waterbath) and for radioactivity using an Electra ${ }^{\mathrm{TM}}$ alpha/beta scintillator, a sodium iodide detector, or equivalents.

- Conduct laboratory analysis of environmental samples for total volatile organic compounds and semivolatile organic compounds. Analysis for radiological contaminants will also be conducted should field screening results exceed background levels. 
- $\quad$ Stage Two

- Perform video survey of the discharge and outfall lines to determine extent, condition, and/or location of collection system components.

- Collect additional environmental samples at step-out locations if field screening levels are exceeded in original sample locations.

- Conduct exploratory trenching and/or borings only if contamination extends beyond the limits of the direct-push equipment.

Additional sampling and analytical details are presented in Section 4.0, and details of the waste management strategy are included in Section 5.0 of this Corrective Action Investigation Plan.

Under the Federal Facility Agreement and Consent Order, the Corrective Action Investigation Plan will be submitted to the Nevada Department of Environmental Protection for approval. Field work will be conducted following approval of the plan. The results of the field investigation will support a defensible evaluation of corrective action alternatives in the Corrective Action Decision Document. 


\subsection{Introduction}

This Corrective Action Investigation Plan (CAIP) for Corrective Action Unit (CAU) 263, the Area 25 Building 4839 Leachfield, has been developed in accordance with the Federal Facility Agreement and Consent Order (FFACO) that was agreed to by the U.S. Department of Energy, Nevada Operations Office (DOE/NV); the State of Nevada Division of Environmental Protection (NDEP); and the U.S. Department of Defense (FFACO, 1996). The CAIP is a document that provides or references all of the specific information for investigation activities associated with CAUs or Corrective Action Sites (CASs). According to the FFACO (1996), CASs are sites potentially requiring corrective action(s) and may include solid waste management units, individual disposal sites, or release sites. Corrective Action Units consist of one or more CASs grouped together based on geography, technical similarity, or agency responsibility for the purpose of determining corrective actions.

This CAIP will be used in conjunction with the Work Plan for Leachfield Corrective Action Units: Nevada Test Site and Tonopah Test Range, Nevada (DOE/NV, 1998d), hereafter referred to as the Leachfield Work Plan (DOE/NV, 1998d). Under the FFACO, a work plan is an optional planning document that provides information for a CAU or group of CAUs where significant commonality exists. This Corrective Action Investigation Plan contains CAU-specific information including a facility description, environmental sample collection objectives, and the criteria for conducting site investigation activities at CAU 263.

This CAIP addresses the CAU 263 Building 4839 Leachfield (CAS 25-05-04) and associated collection system shown in Figure 1-1 (IT, 1998). Figure 1-1 is a composite drawing derived from four archived engineering drawings. These resources are referenced as drawings 25-C5-C1 (REECo, 1984), CSA-PAA-0181, NRDS-SF-P371M-1, and NRDS-SF- P371C-1 (BN, 1997). Building 4839 is located in Area 25 of the Nevada Test Site (NTS). The NTS is approximately 105 kilometers (65 miles) northwest of Las Vegas, Nevada (see Figure 1-1 of the Leachfield Work Plan [DOE/NV, 1998d]).

The septic tank is located approximately 37 meters (m) (120 feet [ft]) southwest of Building 4839, on

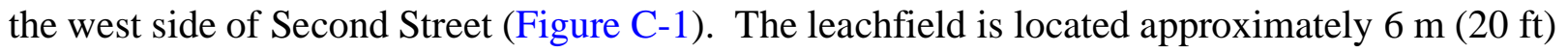




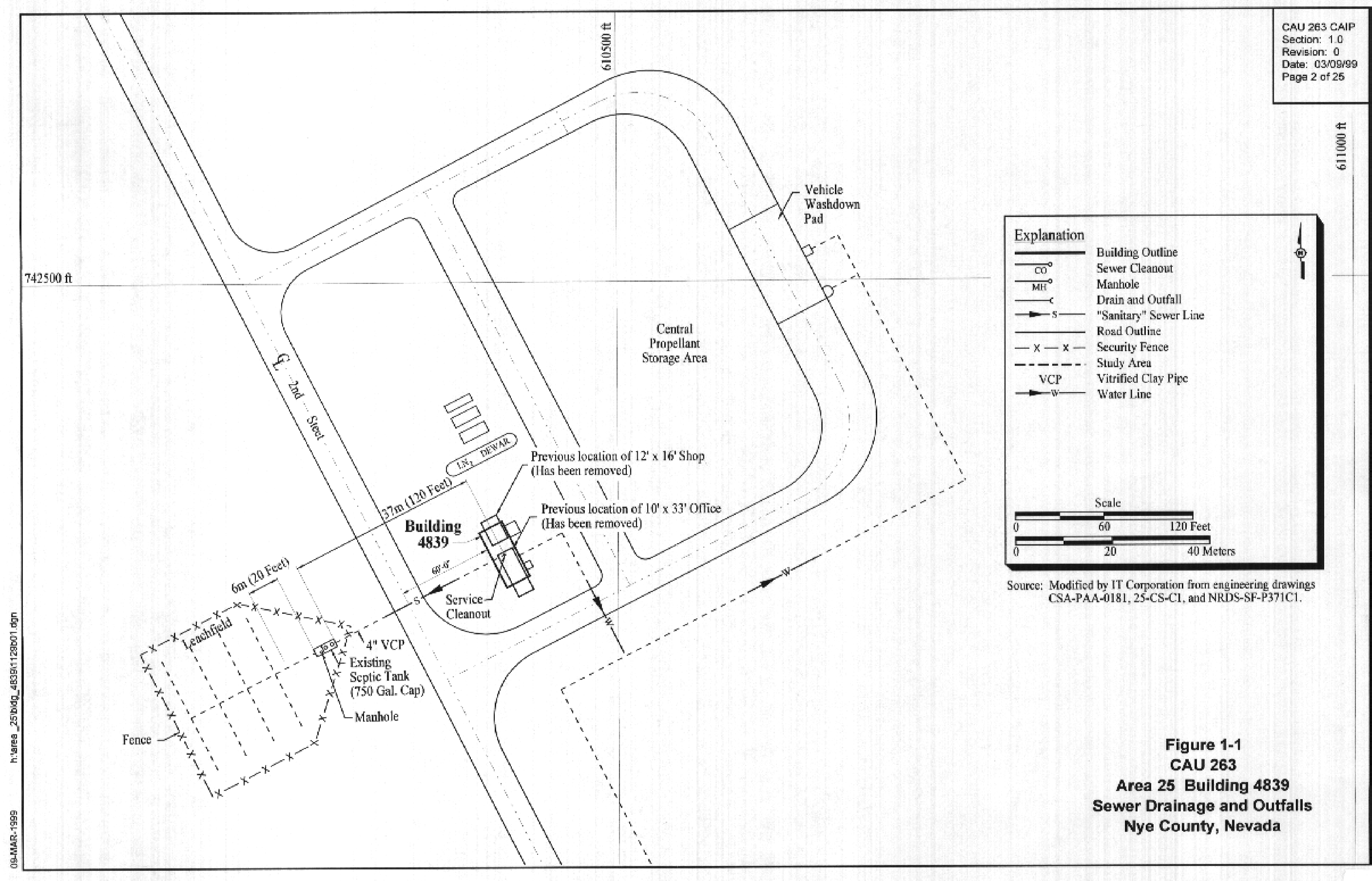


southwest of the septic tank (Figure C-2). A pentagonal fence surrounds both the leachfield and the septic tank and encloses an area of approximately 520 square meters (5,600 square feet) (Figure 1-1). In general, effluent discharged to the leachfield was sanitary wastewater associated with a toilet, a urinal, a lavatory, and a drinking fountain within Building 4839 (Figure C-3). The subsurface soils in the vicinity of the collection system and leachfield may have been impacted by effluent containing contaminants of potential concern (COPCs).

\subsection{Purpose}

This CAIP describes the site-specific details of the investigation to determine the nature and extent of COPCs at CAU 263. The general approach of corrective action investigations for leachfield CAUs is described in the Leachfield Work Plan (DOE/NV, 1998d).

\subsection{Scope}

The scope of this CAIP is to resolve the problem statement identified in the Data Quality Objective (DQO) process which states that sanitary and light industrial effluents may have been released at the $\mathrm{CAU}$, and that existing data are insufficient to support the development and evaluation of potential corrective actions and selection of a preferred corrective action for the CAU. Therefore, the scope of the corrective action investigation at the CAU includes the following activities to answer the problem statement:

- Stage One:

- Conduct initial sampling of the septic tank (this was done previously to support the DQO process).

- Conduct subsurface investigations and sampling in the area surrounding the septic tank, and in specific locations underlying the leachfield using direct-push methods. Should direct-push not prove to be viable due to the composition of leachrock material or the extent of contamination not delineated, Stage Two trenching methods will be used.

- Conduct discrete field screening.

- Collect environmental samples for laboratory analysis of semivolatile organic compounds (SVOCs) and total volatile organic compounds (VOCs). Analysis of radioactivity will also be conducted should field screening results exceed background levels. 
- $\quad$ Stage Two (if required):

- Determine lateral extent of contamination using sample step-out locations.

- Conduct a video survey of subsurface piping.

- Conduct trenching or drilling to locate site elements or to investigate vertical extent of COPCs beyond the limits of the direct-push method.

\subsection{CAIP Contents}

Section 1.0 of this CAIP provides an introduction to this project, including the purpose and scope for this corrective action investigation. The remainder of the document details the investigation strategy. The FFACO (1996) requires that CAIPs address the following elements:

- Management

- Technical aspects

- Quality assurance

- Health and safety

- Public involvement

- Field sampling

- Waste management

The managerial aspects of this project are discussed in the DOE/NV Project Management Plan (DOE/NV, 1994) and the site-specific Field Management Plan that will be developed prior to field activities. The technical aspects of this CAIP are referenced from the Leachfield Work Plan (DOE/NV, 1998d), and contained in Section 3.0 and Section 4.0 of this document and in the DQO summary presented in Appendix A. General field and laboratory quality assurance and quality control (QA/QC) issues, including collection of QC samples, are presented in the Industrial Sites Quality Assurance Project Plan (QAPP) (DOE/NV, 1996b). The health and safety aspects of this project are documented in the Environmental Restoration Project Health and Safety Plan (DOE/NV, 1998b) and will be supplemented with a site-specific health and safety plan written prior to the start of field work. No CAU-specific public involvement activities are planned at this time; however, an overview of public involvement is documented in the "Public Involvement Plan" in Appendix V of the FFACO (1996). Field sampling activities are discussed in the Leachfield Work Plan (DOE/NV, 1998d) and in Section 4.0 of this CAIP and waste management issues are discussed in the Leachfield Work Plan (DOE/NV, 1998d) and in Section 5.0 of this CAIP. The project schedule 
and records availability information for this CAIP are discussed in Section 6.0 of this CAIP. Section 7.0 provides a list of project references. 


\subsection{Facility Description}

General background information pertaining to the history of the NTS and Area 25, a geologic assessment, and an overview of the area hydrogeology including depths to groundwater are provided in the Yucca Mountain Site Characterization Plan (DOE, 1988b) and Appendix A of the Leachfield Work Plan (DOE/NV, 1998d).

\subsection{Physical Setting}

The CAU is located southwest of Building 4839 in Area 25 of the NTS (see Figure 1-1).

\subsection{Operational History}

Building 4839 was constructed in 1968 on a site previously occupied by a shop facility and an office building. The existing sewer line was reconnected to the newly constructed Building 4839 . Building 4839 was also used as an office and a shop facility for the Central Propellant Storage Area (CPSA). The CPSA was designed for sampling liquid hydrogen trucks upon arrival at the Nuclear Rocket Development Station (NRDS). Facilities at the CPSA included a washdown pad, the "K" bottle storage area, and a propellant building (Building 4839). The CAU 263 leachfield system received effluent from a toilet, urinal, lavatory, and drinking fountain in Building 4839. Discharge from the washdown pad was not associated with the Building 4839 leachfield.

Interpretations of engineering drawings and interviews with former employees indicate the CAU 263 leachfield system received sanitary wastewaters. No records of liquid waste quantities discharged through the collection systems were identified.

This leachfield CAU received sanitary effluent from Building 4839. Effluent flowed out of the septic tank through an outfall line into the leachfield itself. A cleanout for the discharge line is located in the floor of Building 4839. Figure 1-1 is a composite drawing compiled from archived engineering drawings CSA-PAA-0181 (Figure C-2), 25-CS-C1 (Figure C-1), and NRDS-SF-P37/C1 (Figure C-4). The lavatory, urinal, and drinking fountain have 5-centimeter $(\mathrm{cm})(2$-inch [in.]) drain lines. The toilet and floor cleanout have 7.6-cm (3-in.) drain lines. All drain lines lead to a 10-cm (4-in.) vitrified clay pipe discharge line that received and channeled the effluent away from 
Building 4839 (Figure C-3). The pipe trends southwest from the sewer cleanout for approximately $18-\mathrm{m}(60-\mathrm{ft})$ to the Second Street pavement centerline, and continues for an additional 18-m (60-ft) before reaching a 2,840-liter (750-gallon) septic tank. The septic tank dimensions are approximately 3-m (8-ft) long, 1-m (4-ft) wide, and 2-m (6-ft) deep. A concrete top allows access to the septic tank that measures 0.6 by $0.6 \mathrm{~m}(2 \mathrm{by} 2 \mathrm{ft})$. An outfall line from the tank extends $7 \mathrm{~m}(23 \mathrm{ft})$ before reaching the first pair of a series of perpendicular pipes within the leachfield. Three more pairs of pipes extend at 6-m (20-ft) intervals from the outfall line. Figure C-2 and Figure C-4 provide details of these components. The distribution pipes were designed to disperse waste into the leachfield.

Construction specifications including the configuration and some details regarding composition and dimensions of the leachfield are provided in Figure C-2. The leachfield measures 18-m (60-ft) long and 42-m (80-ft) wide and is comprised of four pairs of distribution pipes oriented perpendicular to the outfall line in northwest to southeast directions. Each of the distribution pipe pairs consists of two, 12-m (40-ft) lengths of pipe. These pipes are composed of small sections called tiles. The tiles measure $0.3-\mathrm{m}(1-\mathrm{ft})$ in length and $10-\mathrm{cm}(4-\mathrm{in}$.$) in diameter and are spaced 0.6 \mathrm{~cm}(0.3 \mathrm{in}$.$) apart to$ allow effluent disposal. The ends of the distribution pipes are open. The tiles were covered with 15-pound asphalt felt and $8 \mathrm{~cm}$ (3 in.) of straw. The drain tiles were placed on redwood supports to keep the tiles level and embedded in 31-cm (12-in.) deep, 2-cm (0.8-in.) gravel aggregate. Each tile drain line has a 0.4 percent slope (Figure C-2).

\subsection{Waste Inventory}

Information from interviews with former employees (Bielawski, 1998 and Groesbeck, 1998), and interpretations of engineering drawings indicate that sanitary and possibly janitorial cleaning products entered the collection system. No details concerning the waste inventory within the source building during the various years of operation were identified. The quantities of wastewater generated or discharged during the operational periods is unknown (DOE, 1988a). No evidence of routine transfer practices or documentation of liquid waste disposal was revealed in the CAU 263 preliminary assessment phase. 


\section{$2.4 \quad$ Release Information}

The source of potential contamination associated with the collection system is wastewater that was channeled from the Building 4839 toilet, urinal, lavatory, and drinking fountain. The effluent was routed through a single discharge line leading to an in-line septic tank and then into the leachfield. The leachfield was designed for liquid to be dispersed into an area within the installed leachfield material (leachrock), and to percolate down into the underlying native soil. The driving force for downward migration of the contamination was the discharge from the septic tank. The possibility of leakage at points along the collection system exists, but there is no evidence of documented leaks or releases. The leachfield system is now inactive.

\subsection{Investigative Background}

General site investigation activities are described in Section 3.0 of the Leachfield Work Plan (DOE, 1998d). The contents of the CAU 263 septic tank were sampled on November 19, 1998, by employees of the IT Corporation (IT). Three samples were taken from the septic tank associated with the Building 4839 septic system. One sludge sample (CPSA-00002) and two water samples (CPSA-00001 and CPSA 00003) were collected for analysis. The intent of the preliminary sampling was to collect samples most likely to be contaminated to determine the type of COPCs. The samples were analyzed for total Resource Conservation and Recovery Act (RCRA) metals, total VOCs, total SVOCs, and gamma emitting isotopes using the analytical methods prescribed in Table 3-1 of the Leachfield Work Plan. Sample CPSA-00003 was collected as the trip blank and analyzed for VOCs only. Field duplicates were not collected for this sampling site. Constituents detected above the contract required detection limits are listed in Table 2-1. These sampling results depict the most recent discharge to the system and may be representative of the entire history (depending on whether the septic tank has been pumped prior to this sampling). 
Table 2-1

Preliminary Septic Tank Sampling Results

\begin{tabular}{||c|c|c|c|c|c||}
\hline $\begin{array}{c}\text { Sample } \\
\text { Number }\end{array}$ & Parameter & Result & $\begin{array}{c}\text { Instrument } \\
\text { Detection } \\
\text { Limit }\end{array}$ & $\begin{array}{c}\text { Contract } \\
\text { Required } \\
\text { Detection } \\
\text { Limit }\end{array}$ & Units \\
\hline & Barium & 8.22 & 0.133 & 1.0 & $\mathrm{mg} / \mathrm{kg}$ \\
\cline { 2 - 6 } CPSA-00002 & 1,4 -Dichlorobenzene & 5,630 & 17.7 & 250 & $\mu \mathrm{g} / \mathrm{kg}$ \\
\cline { 2 - 6 } & 1,4 -Dichlorobenzene & 5,580 & 1,230 & $3,300^{\mathrm{a}}$ & $\mu \mathrm{g} / \mathrm{kg}$ \\
\cline { 2 - 6 } & p-Isopropyltoluene & 2,620 & 65.7 & 250 & $\mu \mathrm{g} / \mathrm{kg}$ \\
\hline CPSA-00001 & Chromium & 2.05 & 0.0048 & 0.01 & $\mathrm{mg} / \mathrm{L}$ \\
\hline
\end{tabular}

${ }^{\mathrm{a}}$ Diluted sample

$\mathrm{mg} / \mathrm{kg}$ - Milligrams per kilogram

$\mu \mathrm{g} / \mathrm{kg}$ - Micrograms per kilogram

$\mathrm{mg} / \mathrm{L}$ - Milligrams per liter

The chemical data were compared to the Region IX Preliminary Remediation Goals (PRGs) for Industrial Soils (EPA, 1998). None of the constituents exceeded PRGs.

Sample CPSA-00002 contained the constituent 1,4-Dichlorobenzene, which was at a level just below the PRG of 7,300 micrograms per kilogram $(\mu \mathrm{g} / \mathrm{kg})$. Target compound 1,4-Dichlorobenzene is a later-eluting compound in the VOC analysis and an early-eluting compound in the SVOC analysis. Preliminary investigation into the source of this COPC suggests that its presence may be from the deodorizers placed within the basin of the urinal and toilet. Sample CPSA-00002 also revealed the compound p-Isopropyltoluene at 2.6 milligrams per kilogram $(\mathrm{mg} / \mathrm{kg})$ in the volatile analysis. There was no PRG listed for this constituent. This compound is found in volatile oils (Sax and Lewis, 1987), which are used as solvents for janitorial products. The volatile nature of this compound explains why it was not detected in the SVOC analysis, whereas, 1,4-Dichlorobenzene was detected in both VOC and SVOC analysis.

During the DQO meeting, it was determined that samples will be field screened for VOCs and all samples will be submitted for laboratory analysis of both SVOC and VOC constituents.

The results of these samples are anticipated to be representative of the effluent stream discharged to the system subsequent to the most recent septic tank pumping event. It is unknown if septage has ever been removed from this septic tank. 
Site investigation activities associated with CAU 263 have been identified and documented in the Final Environmental Impact Statement for the Nevada Test Site and Off-Site Locations in the State of Nevada (DOE/NV, 1996a).

In accordance with the DOE/NV National Environmental Policy Act (NEPA) compliance program, a NEPA checklist shall be completed prior to the commencement of site investigation activities at CAU 263. This checklist compels DOE/NV projects to evaluate their proposed project against a list of several potential environmental impacts. These include, but are not limited to, air quality, chemical use, waste generation, noise level, and land use. Completion of the checklist results in a determination of the appropriate level of NEPA documentation by the DOE/NV NEPA Compliance Officer. 


\subsection{Objectives}

A discussion of general objectives for leachfield CAUs is presented in Section 3.0 of the Leachfield Work Plan. Objectives addressed in this CAIP are based on the Leachfield Work Plan (DOE/NV, 1998d) and CAU-specific DQOs. Unless otherwise noted, objectives for CAU 263 are identical to those developed in the Leachfield Work Plan (DOE/NV, 1998d).

\subsection{Conceptual Site Model}

The conceptual model for CAU 263 is analogous to the general leachfield conceptual model presented in Section 3.1 of the Leachfield Work Plan (DOE/NV, 1998d). The scope and strategy of this investigation may be revised if the conceptual model provided in this CAIP and applicable portions of the conceptual model provided in the Leachfield Work Plan (DOE/NV, 1998d) fail. The CAU 263 conceptual model may fail if substantially different historical operational information is discovered, or field observations demonstrate the nature or extent of contamination associated with the CAU is substantially different than anticipated. If necessary, a rescoping of the investigation will be conducted.

\subsection{Contaminants of Potential Concern}

Potential types of contaminants that could be present were identified through a review of site history documentation, subjective process knowledge, inferred activities associated with the CAU, and preliminary sampling of the septic tank associated with the collection system. Contaminants identified during the sampling of the septic tank are expected to be representative of COPCs in the leachfield. Contaminants are expected to be similar to those in septage from sanitary sewage systems. Laboratory analysis of the soil samples will provide the means for a quantitative measurement of the COPCs. The following analytes will be measured to determine the nature of potential contamination at CAU 263:

- Total VOCs

- Total SVOCs

- Radionuclides through gamma spectroscopy if field screening results exceed field screening levels 
The analytical methods and minimum reporting limits for each analyte are provided in Table 3-1 in the Leachfield Work Plan. Minimum reporting limits for gamma-emitting radionuclides are 0.2 picocuries per gram for soil and 20 picocuries per liter for water (DOE/NV, 1996b).

\subsection{Preliminary Action Levels}

Screening levels for on-site field screening methods and preliminary action levels (PALs) for off-site analytical methods will be used to determine the presence of contamination. The screening levels and PALs are provided in Section 3.3 of the Leachfield Work Plan (DOE/NV, 1998d) and were agreed upon during the CAU-specific DQO process.

\subsection{DQO Process Discussion}

Details of the DQO process are presented in Appendix A. The DQO results for CAU 263 indicated the need for a biased sampling approach. Due to potential subsurface migration of COPCs, an investigation consisting of subsurface sampling was identified. The applicable COPCs, analytical methods, and reporting limits agreed upon during the DQO process are included in Section 3.2 and Table 3-1 of the Leachfield Work Plan (DOE/NV, 1998d). Data quality will be verified and evaluated as stated in the Leachfield Work Plan (DOE/NV, 1998d). 


\subsection{Field Investigation}

The investigation activities to be performed at CAU 263 are based on general field investigation activities discussed in Section 4.0 of the Leachfield Work Plan (DOE/NV, 1998d).

\subsection{Technical Approach}

The technical approach for CAU 263 will be conducted in Stage One and Stage Two (if required) and consists of the following activities:

- $\quad$ Stage One:

- Collect samples from within the septic tank. This activity was done preliminarily to support the DQO process. A description of this sampling effort is provided in Section 2.5.

- Collect subsurface samples from both ends of the septic tank and various locations within the leachfield boundaries using a direct-push method. Should direct-push not prove to be a viable method due to the composition of leachrock material or the extent of contamination not delineated, Stage Two trenching methods will be used.

- Collect samples from 20 nearby undisturbed locations to obtain field screening levels for radioactivity; establish the field-screening levels at the mean plus two standard deviations of the 20 readings.

- Conduct field screening for VOCs using headspace method (photoionization detector [PID] and waterbath) and radioactivity using an Electra ${ }^{\mathrm{TM}}$ alpha/beta scintillator, a sodium iodide detector, or equivalents.

- Conduct laboratory analysis of environmental samples for total VOCs and SVOCs. Analysis of radiological contaminants will be conducted if field screening results exceed field-screening levels.

- $\quad$ Stage Two

- Perform video survey of the discharge and outfall lines to determine extent, condition, and/or location of collection system component.

- Collect additional environmental samples at step-out locations if field screening levels are exceeded in original sample locations. 
- Conduct exploratory trenching and/or borings if contamination extends beyond the limits of the direct-push equipment.

- Samples will be collected at locations where the vertical extent of contamination was not bounded by Stage One sampling techniques.

This investigation strategy will allow the extent of contamination associated with the leachfield system to be established. In general, the soil underlying the leachfield will be investigated in Stage One using direct-push methods to determine the extent of contamination. If field screening or PALs provided in Section 3.3 are exceeded and contamination appears more extensive than anticipated, Stage Two methods may be employed. If Stage Two sampling is conducted, the soils underlying the leachfield and potentially soils associated with the collection system will be investigated until soil samples with contaminant concentrations below appropriate field screening levels (as stated in Section 3.3) are obtained from two consecutive intervals. If contamination is more extensive than anticipated and drilling or excavation activities are necessary, the maximum investigation depth will be limited by the capability of the equipment. If this occurs, the investigation will be rescoped.

\subsection{Field Activities}

The investigation of the CAU 263 leachfield system will consider both accidental and designed effluent releases. While leachfields are designed to release effluent to the underlying soil, collection system releases are typically caused by a loss of system integrity. The effect of accidental releases will be assumed to be minimal unless contamination exceeding PALs is detected during Stage One sample analysis. Potential accidental releases will be identified by sampling soil outside the septic tank. The impact of designed releases will be determined by sampling the septic tank contents and soil underlying the leachfield.

The first stage sampling results will be used to determine contamination extent. If field screening or analytical results indicate contamination extent is not defined because concentrations exceed specified field screening levels or PALs, second stage methods will be employed. Additional samples may be collected at specific collection system features based on the video survey results if Stage Two sampling is required. 
All sampling activities will be conducted in compliance with the Industrial Sites QAPP

(DOE/NV, 1996b). Requirements for field and laboratory environmental sampling are contained in the Industrial Sites QAPP (DOE/NV, 1996b) and the Leachfield Work Plan (DOE/NV, 1998d).

\subsubsection{Stage One Activities}

Sampling, using direct-push methods (i.e., Geoprobe ${ }^{\circledR}$ ), will be the primary investigation tool for this leachfield system. Sampling locations will be based on interpretation of engineering drawings, and surface features. The composition of the leachrock material may hinder investigations. The extent of the contamination may not be defined by Stage One activities. Should direct-push not prove to be a viable method, Stage Two trenching and/or drilling methods will be used. Contingent investigations are discussed in Section 4.0 of the Leachfield Work Plan (DOE/NV, 1998d).

\subsubsection{Sampling of Septic Tank}

The septic tank contents were sampled and analyzed to determine the nature of the discharge to the leachfield system. Samples were collected using a 9-liter (2-gallon) polyurethane bucket connected to a nylon rope. The bucket was lowered by rope into the septic tank and samples were collected from the septic tank. Samples were collected from both the liquid phase and underlying solid phase of the septic tank contents. The liquid phase was clear with no apparent odor. The sludge sample was collected by scraping the bucket along the bottom of the septic tank. The sludge appeared dark green to gray in color, was light weight, and settled slowly in the water, indicating small particulate size. These two samples and a trip blank used for quality assurance and control were submitted for analysis to EMAX Laboratories in Torrance, California.

\subsubsection{Direct-Push Method}

The direct-push sampling will occur at both ends of the septic tank, directly above the estimated location of outfall line and distribution line connections, and at additional locations within the leachfield (see Figure 4-1). The two samples between the first and second (north and south trending) leach lines have been placed to verify the orientation of the distribution lines. Limited excavations may be used to verify or establish the pipe orientation and location if these cannot be reasonably estimated based on surface features and engineering drawings. 


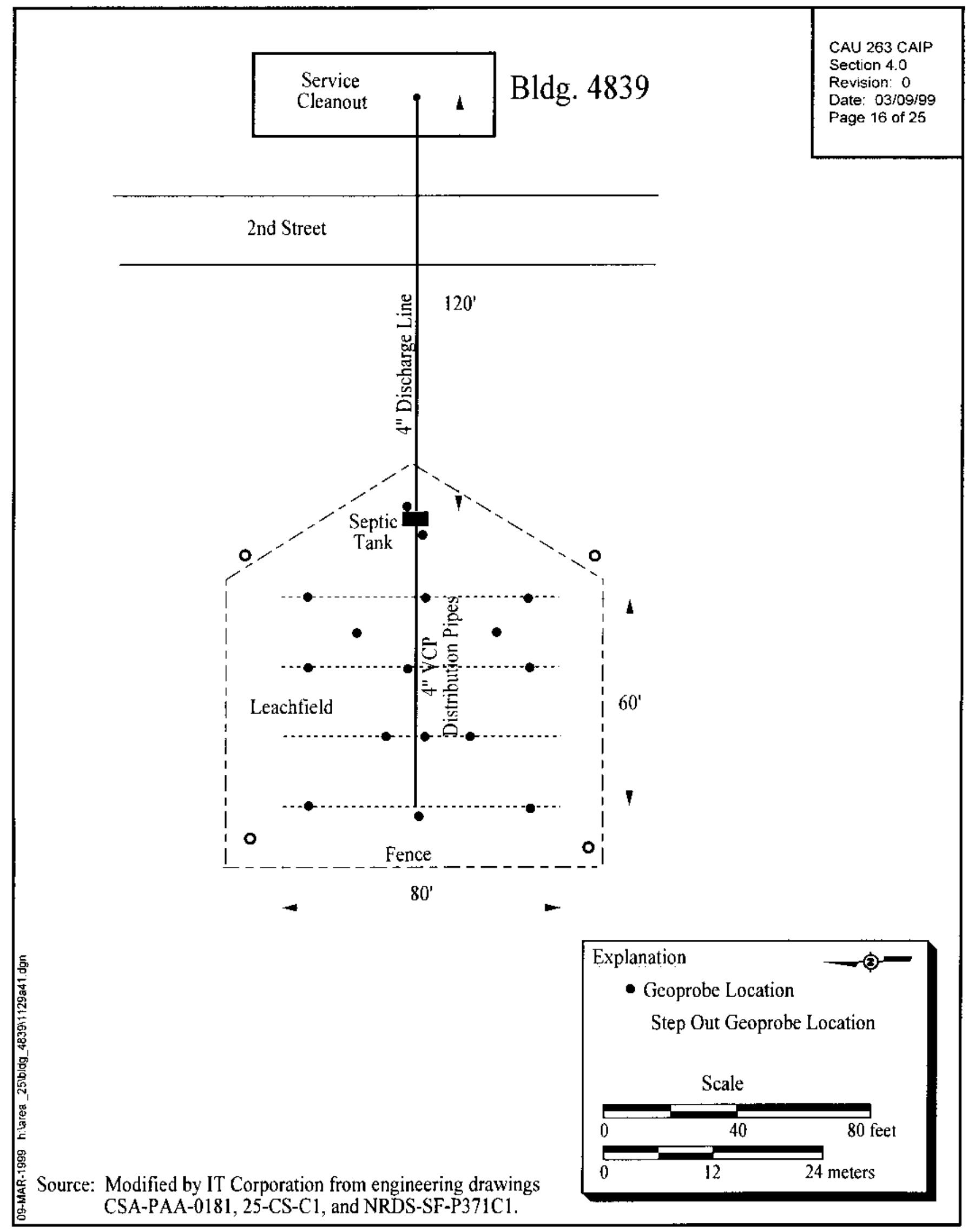

Figure 4-1

CAU 263

Proposed Sampling Locations 
Direct-push activities will expose just enough material to access the required sampling horizons and will be conducted within the leachfield boundaries and along the collection lines. One sample will be collected at each of the 14 locations within the leachfield at two separate depth intervals. Soil samples in the leachfield will be collected at approximately 0.6 to $0.9-\mathrm{m}$ (2.0 to 3.0-ft) below ground surface (bgs) and 1.8 to $2.1-\mathrm{m}$ (6.0 to 7.0-ft) bgs. This is the estimated depth of connecting collection system piping and components at this portion of the leachfield. Soil samples will be collected from the inlet and outlet sides of the septic tank at approximately 1.2 to $1.5-\mathrm{m}$ (4.0 to $5.0-\mathrm{ft}$ ) bgs and 2.7 to 3.1-m (9.0 to 10.0-ft) bgs. These samples will be representative of soil likely to have been impacted if leakage associated with the leachfield system occurred.

Soil from near the bottom of each sample interval within the core barrel sampler will be packed in appropriate sample containers immediately upon retrieval. Only material (soil) suitable for sampling will be submitted to the laboratory for analysis. Leachrock will not be sampled. In general, the first portion of soil will be retained for the analytes most sensitive to volatilization (VOCs). The next portion will be retained for field screening of SVOCs. The third portion, if needed, will be retained for other analytes, such as the radiological components. The remaining soil will be used if additional sample volume is needed for samples that are not sensitive to volatilization. If extra volume for a given sampling event is required, then sample collection will be extended laterally at the same depth.

If results show that contaminant concentrations exceed field screening levels and/or PALs, a second stage of samples will be collected using direct-push, trenching, and/or boring methods (described in Section 4.2.2).

\subsubsection{Field Screening Method}

The entire core collected during the direct-push method will be field screened for elevated radiological activity (i.e., alpha/beta) prior to sample aliquot collection. The same aliquot partitioning, sample handling, and screening will be adapted for either the trenching or drilling alternatives in the Stage Two activities as required.

Field screening methodology is discussed in Section 4.1.3 of the Leachfield Work Plan (DOE/NV, 1998d). Field screening for VOC and radiological activity will be performed to guide the 
investigation and sampling selection and to assist with health and safety and waste management decisions.

\subsubsection{Laboratory Analysis}

Soil samples will be collected for laboratory analysis at all the initial biased sample locations. Samples submitted to the laboratory will be analyzed in accordance with Table 3-1 in the Leachfield Work Plan (DOE/NV, 1998d). If there is a need for step-out sampling, samples will be collected for laboratory analysis from the highest field screening interval and from the first of the two consecutive, intervals below field-screening levels. If field screening does not detect any contamination in the step-out samples, the first of the two consecutive samples below field screening levels will be submitted to the laboratory for confirmation of the nondetect field screening readings. Proposed analytical parameters were selected based on process and historical knowledge, sampling data, and discussions during the DQO process. The parameters, methods, and associated QC ranges for precision and accuracy measurements are specified in Table 3-1 in the Leachfield Work Plan (DOE/NV, 1998d). All laboratory samples from the proposed initial samples and step-outs, if required, will be analyzed for the following constituents:

\section{- Total VOCs}

- Total SVOCs

- Radionuclides through gamma spectroscopy (if field screening results exceed background levels)

Environmental samples that will be packaged and shipped for laboratory analysis will be collected immediately upon retrieval from the subsurface. Analytical samples will be submitted to the laboratory in appropriate sample containers. Discretionary sampling points may also be selected for laboratory analysis based on visual examination by the Site Supervisor. Selection criteria for discretionary samples may include:

- Moist or discolored zones

- Significant changes in soil grain size

- Odor 
All sampling equipment which contacts soil will be decontaminated in accordance with written and approved procedures consistent with the Environmental Restoration Division (ERD) Procedure ERD-05-701, “Sampling Equipment Decontamination,” Rev. 1 (DOE/NV, 1998c), or as appropriate for special equipment being decontaminated (i.e., decontaminating core barrels). Core barrels (including direct-push barrels), if used, will be decontaminated prior to each sampling event and between boreholes to minimize the potential for cross-contamination of samples from different sample locations or depths (see Section 4.1.4.2 of the Leachfield Work Plan [DOE/NV, 1998d]).

Records will be maintained for a visual classification of the soil, field screening measurements, and all other relevant data. Pertinent and required sampling information (e.g., date, time, sample interval) will be documented in accordance with the Industrial Sites QAPP (DOE/NV, 1996b). Approved chain of custody procedures will be followed to assure data defensibility (DOE/NV, 1998a).

If the sampling results indicate that the concentrations exceed specified PALs for confirmatory "clean" samples, the conceptual model or field screening may have failed. If this occurs, the extent of the contamination has not been resolved and additional locations may be selected (i.e., lateral step-outs) and/or surface investigations may be conducted to further track the vertical extent of contamination.

\subsubsection{Stage Two Activities}

Additional investigation may consist of a combination of activities. Video surveys may be taken of the interior of the discharge and outfall lines to inspect the pipes associated with the collection system. Trenching and/or drilling may be conducted within the leachfield to determine the vertical extent of contamination. Step-out, direct-push methods may also be used to establish lateral contamination extent.

\subsubsection{Video Survey}

A video survey may be conducted inside the discharge and outfall lines to inspect the pipes associated with the collection system. The collection system will be mapped by following the piping, and locating or ruling out the existence of other possible tie-ins. This survey may not be possible for 
some lines because of small pipe diameters (i.e., less than 7.5-cm [3-in.] diameter), limited access, pipe damage, blockage, or other factors.

The camera and cable system will be introduced through the septic tank cover or the cleanout in Building 4839. Other entry points may be accessed by excavating at the required locations. The specific manner of conducting the video survey is discussed in Section 4.1.1.4 of the Leachfield Work Plan (DOE/NV, 1998d). Excavation may be required to expose the discharge or outfall lines if access through the septic tank is not possible.

The video survey will evaluate the current physical condition and layout of the leachfield system. Video surveys allow a visual assessment of the system's integrity and can be used to identify obvious breaches, unexpected branchings (i.e., tie-ins or off-shoots), and open joints. If a tie-in is discovered, the line will be investigated to the source (if possible) and sampling activities will be suspended until an action consensus is reached between members of the scoping team. The discovery of an unexpected contributing line may imply an additional source input and could increase the scope of the investigation.

\subsubsection{Excavation and Trenching Activities}

Should the Geoprobe ${ }^{\circledR}$ method of investigation be deemed inconclusive or unfeasible due to incomplete investigation and/or impassible site conditions, alternate types of intrusive methods will be proposed. These methods may include trenching and/or drilling activities. Excavation locations will be based on Stage One results, interpretation of engineering drawings, surface features, and video surveys. Excavated soil will be stored in a manner which will prevent run-on and run-off. Soil excavated during trenching operations will be returned to the excavation as close to its original location as possible upon completion of the excavation investigation activities.

Boreholes and/or trenches will be advanced to depths adequate to determine the vertical extent of contamination. Samples will be collected directly from excavations or the backhoe bucket at approximately $1.5-\mathrm{m}(5-\mathrm{ft})$ intervals beginning at the greatest depth that contamination exceeding field screening levels or PALs was detected at adjacent first-stage sample locations. Sample collection will begin at the established leachfield base depth if boreholes without associated first-stage sample locations are required. If results show that contaminant concentrations exceed field 
screening levels and/or PALs, additional samples will be collected as step-outs or at greater depths below the first stage of samples.

At least one sample will be submitted from each borehole. If contamination is detected by field screening, the sample with the highest contamination concentration will be submitted. Additional samples may be submitted at the discretion of the Site Supervisor and to support Waste Management.

Alternative approaches outlining borehole placement strategies should certain site conditions be encountered are addressed in Section 4.1.2 of the Leachfield Work Plan (DOE/NV, 1998d).

\subsubsection{Step-Out Direct Push Methods}

Initial step-out Geoprobe ${ }^{\circledR}$ samples will be drilled $4.6 \mathrm{~m}(15 \mathrm{ft})$ outside the margins of the leachfield (see Section 4.1.2.1 of the Leachfield Work Plan [DOE/NV, 1998d]). 


\subsection{Waste Management}

Waste management activities to be performed for CAU 263 are addressed in Section 5.0 of the Leachfield Work Plan (DOE/NV, 1998d). All potential waste types and waste streams associated with the leachfield CAUs are covered in the Leachfield Work Plan (DOE/NV, 1998d).

\subsection{Waste Minimization}

Waste will be managed according to hazardous waste requirements until laboratory analyses are received and a final waste determination is made. If field screening or laboratory analysis indicates radiological activity above background levels, the waste will subsequently be managed according to the mixed waste requirements addressed in the Leachfield Work Plan (DOE/NV, 1998d).

\subsection{Potential Waste Streams}

Based on process knowledge obtained for CAU 263, possible hazardous wastes are anticipated at this site. There is no process knowledge that suggests a specific "listed" hazardous waste may have been discharged to this leachfield; therefore, if contaminants are identified, it is likely they would be characteristic rather than listed hazardous wastes. Radiological contamination may be present but is not expected. Action levels for investigation-derived waste (IDW) contaminants are as stated in Table 5-1 of the Leachfield Work Plan (DOE/NV, 1998d). Polychlorinated biphenyls are not anticipated COPCs at CAU 263.

\subsection{Investigation-Derived Management}

Any IDW generated during this investigation will be segregated by waste stream and placed in U.S. Department of Transportation (DOT)-compliant containers appropriate for the type and amount of waste generated. The IDW generated at CAU 263 will be contained in DOT-compliant containers meeting the specifications outlined in the Leachfield Work Plan (DOE/NV, 1998d). 


\subsection{Duration and Records Availability}

\subsection{Duration}

After submittal of the Final CAIP for CAU 263 to NDEP (FFACO milestone deadline of May 31, 1999), the following is a tentative schedule of activities (in calendar days):

- Day 0: Preparation for field work will begin.

- Day 60: The field work, including field screening and sampling, will begin. Samples will be shipped to meet laboratory holding times.

- Day 110: The field work will be completed.

- Day 185: The quality-assured laboratory analytical sample data will be available for NDEP review.

- The FFACO date for the Corrective Action Decision Document (CADD) is January 31, 2000.

\subsection{Records Availability}

This document is available in the U.S. Department of Energy (DOE) public reading rooms located in Las Vegas and Carson City, Nevada, or by contacting the DOE/NV Project Manager. The NDEP maintains the official Administrative Record for all activities conducted under the auspices of the FFACO. 


\subsection{References}

Bielawski, J. Bechtel Nevada (formerly). 1998. Record of Telecon with R. Johnson (HSI GeoTrans [formerly]) regarding Building 4839 Sewage System, 10 March. Las Vegas, NV.

BN, see Bechtel Nevada.

Bechtel Nevada. 1997. Engineering Drawings Index Standard Report, drawings CSA-PAA-0181, NRDS-SF-P371M1, and NRDS-SF-P371C-1. Las Vegas, NV.

DOE, see U.S. Department of Energy.

DOE/NV, see U.S. Department of Energy, Nevada Operations Office.

EPA, see U.S. Environmental Protection Agency.

FFACO, see Federal Facility Agreement and Consent Order.

Federal Facility Agreement and Consent Order. 1996. Agreed to by the State of Nevada, the U.S. Department of Energy, and the U.S. Department of Defense.

Groesbeck, A. REECo (Retired). 1998. Record of Telecon with Carl Speer (Science Applications International Corporation) regarding Building 4839 Sewage System, 10 June. Las Vegas, NV.

IT Corporation. 1998. Modified engineering drawing using maps provided by Bechtel Nevada Archives and Records Center, Mercury, NV. Las Vegas, NV.

REECo, see Reynolds Electrical and Engineering Company, Inc.

Reynolds Electrical and Engineering Company, Inc. 1984. "Existing Water \& Sewer Layout Central Support Area Plan, Map No. 25-CS-C1." Las Vegas, NV.

Sax, N.I., and R.J. Lewis, Sr. 1987. Hazardous Chemicals Desk Reference. New York: Van Nostrand Reinhold Company Inc.

U.S. Department of Energy. 1988a. Environmental Survey Preliminary Report, Nevada Test Site, Nevada, DOE/EH/OEV-15P. Washington, DC: Environment, Safety and Health, Office of Environmental Audit.

U.S. Department of Energy. 1988b. Site Characterization Plan, Yucca Mountain Site, Nevada, DOE/RW - 0199, Vols. I-IX. Las Vegas, NV. 
U.S. Department of Energy, Nevada Operations Office. 1994. Project Management Plan, Rev. 0. Las Vegas, NV.

U.S. Department of Energy, Nevada Operations Office. 1996a. Final Environmental Impact Statement for the Nevada Test Site and Off-Site Locations in the State of Nevada, DOE/EIS 0243, Las Vegas, NV.

U.S. Department of Energy, Nevada Operations Office. 1996b. Industrial Sites Quality Assurance Project Plan, Nevada Test Site, Nevada, DOE/NV--372. Las Vegas, NV.

U.S. Department of Energy, Nevada Operation Office. 1998a. ERD-05-201, "Chain of Custody," Rev. 1. Las Vegas, NV.

U.S. Department of Energy, Nevada Operations Office. 1998b. Environmental Restoration Health and Safety Plan, Rev. 3. Las Vegas, NV.

U.S. Department of Energy, Nevada Operation Office. 1998c. ERD-05-701, "Sampling Equipment Decontamination," Rev. 1. Las Vegas, NV.

U.S. Department of Energy, Nevada Operations Office. 1998d. Work Plan for Leachfield Corrective Action Units: Nevada Test Site and Tonopah Test Range, Nevada, DOE/NV--514.

Las Vegas, NV.

U.S. Environmental Protection Agency. 1998. Memo from S.J. Smucker regarding Region 9 Preliminary Remediation Goals (PRGs), 1 August. San Francisco, CA. 
Appendix A

\section{Data Quality Objectives Worksheets}




\section{A.1.0 Introduction}

\section{A.1.1 Problem Statement}

Potentially hazardous wastes were discharged to the Area 25 Building 4839 Leachfield System (CAU 263). Corrective Action Unit 263 consists of a single CAS, namely CAS 25-05-04. Existing information about the nature and extent of contamination is insufficient to evaluate and select preferred corrective actions for this site.

This CAU will be investigated based on DQOs developed by representatives of the NDEP and DOE/NV. This investigation will determine if COPCs are present and if concentrations exceed preliminary action levels in soils underlying the leachfield. If COPCs are detected, the lateral and vertical extent of contamination will be delineated. Data adequate to close the site under NDEP, RCRA, and DOE requirements will be collected.

\section{A.1.2 DQO Kickoff Meeting}

Table A.1-1 lists the participants present at the FFACO-required DQO Kickoff Meeting. The goal of the DQO process is to establish the quantity and quality of environmental data required to support corrective action decisions for the CAU. The process ensures that the information collected will provide sufficient and reliable information to identify, evaluate, and technically defend the chosen corrective action. Unless otherwise required by the results of this DQO and stated in the CAIP, this investigation will adhere to the Industrial Sites QAPP (DOE/NV, 1996). This site will be investigated based on the general strategies provided in the Work Plan for Leachfield Corrective Action Units: Nevada Test Site and Tonopah Test Range, Nevada, hereafter referred to as the Leachfield Work Plan (DOE/NV, 1998). Site-specific deviations from the Leachfield Work Plan will be identified in this document and the CAIP. 
Table A.1-1

DQO Kickoff Meeting Participants

\begin{tabular}{||l|l|c||}
\hline \multirow{2}{*}{ Participant } & \multirow{2}{*}{ Affiliation } & Meeting Date \\
\cline { 3 - 3 } & & $\begin{array}{c}\text { Kickoff Meeting } \\
\text { December 2, 1998 }\end{array}$ \\
\hline \hline Frank Baird & IT & $\mathrm{X}$ \\
\hline Clayton Barrow & DOE/NV & $\mathrm{X}$ \\
\hline Rob Boehlecke & IT & $\mathrm{X}$ \\
\hline Jerry Bonn & BN & $\mathrm{X}$ \\
\hline Lydia Coleman & SAIC & $\mathrm{X}$ \\
\hline Mark DiStefano & IT & $\mathrm{X}$ \\
\hline Candice Fillmore & SAIC & $\mathrm{X}$ \\
\hline Syl Hersh & IT & $\mathrm{X}$ \\
\hline Greg Raab & NDEP & $\mathrm{X}$ \\
\hline Mary Todd & SAIC & $\mathrm{X}$ \\
\hline Jeanne Wightman & MACTEC & $\mathrm{X}$ \\
\hline Dustin Wilson & SAIC & $\mathrm{X}$ \\
\hline \hline
\end{tabular}

IT - IT Corporation

BN - Bechtel Nevada

SAIC - Science Applications International Corporation 


\section{A.2.0 Conceptual Model}

The conceptual site model describes the most probable scenario for current conditions at CAU 263. The presence of COPCs within soils is the result of designed releases of contaminated effluent to the leachfield or accidental releases from collection system components, including the septic tank and damaged discharge and outfall lines. A general conceptual site model for leachfield systems is provided in the Leachfield Work Plan. Site-specific information is included in the conceptual model for the CAU 263 Leachfield in Table A.2-1. 
Table A.2-1

Conceptual Model for the CAU 263 Leachfield System

\begin{tabular}{|c|c|c|}
\hline $\begin{array}{l}\text { Conceptual Model } \\
\text { Element }\end{array}$ & Assumptions & Source \\
\hline \multirow{3}{*}{ System dynamics } & $\begin{array}{l}\text { Infiltration and concentration of contaminants in the form } \\
\text { of liquid waste into the soil directly below (surrounding) } \\
\text { the leachlines and within the leachfield may have } \\
\text { occurred. }\end{array}$ & $\begin{array}{l}\text { Knowledge of similar } \\
\text { sites }\end{array}$ \\
\hline & $\begin{array}{l}\text { Downward migration of contaminants is not likely due to } \\
\text { the depth to ground water; approximately } 1,047 \mathrm{ft} \text {. } \\
\text { Groundwater contamination is unlikely due to } \\
\text { environmental conditions at the site, such as an arid } \\
\text { climate and low permeabilities. }\end{array}$ & $\begin{array}{l}\text { Knowledge of similar } \\
\text { sites }\end{array}$ \\
\hline & $\begin{array}{l}\text { No driving forces other than limited precipitation and } \\
\text { infiltration. Also, fluid inputs through the piping have not } \\
\text { occurred since cessation of operations. Building } 4839 \\
\text { was closed in } 1996 \text {. }\end{array}$ & Process knowledge \\
\hline Source location & $\begin{array}{l}\text { The contributing drains from within the Building } 4839 \\
\text { source room are clearly defined. The physical } \\
\text { components of the collection system drains and locations } \\
\text { of the piping and leachfield are assumed based on } \\
\text { engineering drawings. The septic tank can be physically } \\
\text { located (evident surface expressions) in the field. }\end{array}$ & $\begin{array}{l}\text { Archival engineering } \\
\text { drawings and site visits }\end{array}$ \\
\hline \multirow{2}{*}{$\begin{array}{l}\text { Lateral extent of } \\
\text { potential contaminants }\end{array}$} & $\begin{array}{l}\text { Subsurface effects are limited by relatively low } \\
\text { contaminant concentrations and volume and/or low } \\
\text { mobility of constituents. }\end{array}$ & Process knowledge \\
\hline & $\begin{array}{l}\text { The potential lateral migration of contaminants is } \\
\text { unknown, but if migration has occurred, it will likely be } \\
\text { confined to the boundaries of the leachfield system. }\end{array}$ & $\begin{array}{l}\text { Knowledge of similar } \\
\text { sites. }\end{array}$ \\
\hline $\begin{array}{l}\text { Vertical extent of } \\
\text { potential contaminants }\end{array}$ & $\begin{array}{l}\text { The vertical extent of potential contamination is unknown } \\
\text { but most likely (if existent) will be directly below } \\
\text { (surrounding) the leachlines and within the leachfield as } \\
\text { vertical extent would be limited by low contaminant } \\
\text { concentrations and volumes, lack of driving force, } \\
\text { relatively low mobility of COPCs. }\end{array}$ & $\begin{array}{l}\text { Knowledge of similar } \\
\text { sites. }\end{array}$ \\
\hline $\begin{array}{l}\text { Physical and practical } \\
\text { constraints }\end{array}$ & $\begin{array}{l}\text { Nearby utilities and buildings; adverse weather } \\
\text { conditions; restricted access; heavy equipment and } \\
\text { resource availability; health and safety concerns; } \\
\text { approval of the CAIP }\end{array}$ & Site knowledge \\
\hline Future use & $\begin{array}{l}\text { Area } 25 \text { would be a monitored and restricted area within } \\
\text { the NTS. }\end{array}$ & $\begin{array}{l}\text { Assumptions are defined } \\
\text { in the Final } \\
\text { Environmental Impact } \\
\text { Statement for the Nevada } \\
\text { Test Site and Off-Site } \\
\text { Locations in the State of } \\
\text { Nevada (DOE/NV, } \\
\text { 1996a) }\end{array}$ \\
\hline Potential exposures & $\begin{array}{l}\text { Oral ingestion, inhalation, or dermal contact (absorption) } \\
\text { of COPCs in the soil due to inadvertent exposure during } \\
\text { excavation }\end{array}$ & Process knowledge \\
\hline
\end{tabular}




\section{A.3.0 Potential Contaminants}

Section 3.0 of the CAIP and the Leachfield Work Plan provide additional information on the COPCs for this CAU, including field-screening levels, PALs, and QA/QC requirements.

The CAU 263 Leachfield received effluent consisting of sanitary wastewaters from lavatory facilities and associated janitorial activities. Trace amounts of VOCs and SVOCs produced by janitorial activities may be present in the soil associated with the leachfield. Field screening for VOCs using headspace method (PID and waterbath) and for radioactivity (using an Electra ${ }^{\mathrm{TM}}$ alpha/beta scintillation detector and sodium iodide detector or equivalents) will be conducted as a precautionary measure. The COPCs for this CAU consist of VOCs and SVOCs; these will be analyzed according to Table 3-1 of the Leachfield Work Plan. If radioactivity is detected above field-screening levels as defined in Section 3.3 of the Leachfield Work Plan, samples will be analyzed according to Table 3-1 in the Leachfield Work Plan. If radioactivity is identified above field-screening levels, analysis for gamma-emitting radionuclides will be conducted through gamma spectroscopy. 


\section{A.4.0 Decisions and Inputs}

\section{A.4.1 Decisions}

Decisions to be resolved by the investigation include:

- Determine if COPCs are present at the site.

- Determine if COPC concentrations exceed field screening levels.

- Determine if COPC concentrations exceed PALs.

- Determine the nature and extent of contamination with enough certainty to develop and evaluate a range of potential corrective actions, including closure in place and clean closure. Inputs and Strategy

Inputs to the decisions include those elements of information used to support the decisions in addressing the identified problem. A list of information inputs, existing data, identified data gaps, and brief strategies are discussed in Table A.4-1. A more detailed discussion of investigation strategies is found in Section A.5.0. 
Table A.4-1

Decisions, Inputs, and General Strategies

(Page 1 of 2)

\begin{tabular}{|c|c|c|c|c|}
\hline Decision & Input & Existing Data & Data Gap & Strategy \\
\hline \multirow{4}{*}{$\begin{array}{l}\text { Are COPCs present } \\
\text { above PALs at site? }\end{array}$} & $\begin{array}{c}\text { Potential } \\
\text { contaminant } \\
\text { identification }\end{array}$ & $\begin{array}{c}\text { Potentially-contaminated effluent associated with } \\
\text { lavatory facilities and associated janitorial } \\
\text { activities }\end{array}$ & Exact COPCs & $\begin{array}{l}\text { Collect laboratory samples; } \\
\text { analyze for COPCs }\end{array}$ \\
\hline & $\begin{array}{l}\text { Potential } \\
\text { contaminant } \\
\text { concentration }\end{array}$ & $\begin{array}{l}\text { Preliminary sampling data available for the septic } \\
\text { tank; should provide worst-case for contaminant } \\
\text { concentration }\end{array}$ & $\begin{array}{c}\text { COPC } \\
\text { concentrations in } \\
\text { the leachfield; do } \\
\text { concentrations } \\
\text { exceed PALs? }\end{array}$ & $\begin{array}{l}\text { Collect field screening and } \\
\text { laboratory samples at planned } \\
\text { locations; compare results to } \\
\text { field screening levels or to } \\
\text { PALs }\end{array}$ \\
\hline & \multirow[t]{2}{*}{$\begin{array}{l}\text { Potential } \\
\text { contaminant } \\
\text { distribution }\end{array}$} & $\begin{array}{l}\text { Vertical extent of COPCs may extend below the } \\
\text { leachfield into underlying soil }\end{array}$ & $\begin{array}{l}\text { Exact vertical } \\
\text { extent }\end{array}$ & $\begin{array}{l}\text { Sample using direct-push } \\
\text { technique to define vertical } \\
\text { extent of contamination; if } \\
\text { contamination extends } \\
\text { beyond direct-push limit, } \\
\text { conduct second stage using } \\
\text { trenching or drilling to } \\
\text { determine maximum vertical } \\
\text { extent of COPCs; collect } \\
\text { confirmatory laboratory } \\
\text { samples }\end{array}$ \\
\hline & & $\begin{array}{l}\text { Lateral extent of COPCs may extend beyond the } \\
\text { leachfield margins into surrounding soil }\end{array}$ & Exact lateral extent & $\begin{array}{l}\text { If COPCs exceed PALs, } \\
\text { conduct second stage } \\
\text { investigation using } \\
\text { direct-push, trenching, or } \\
\text { drilling to determine lateral } \\
\text { extent of COPCs; collect } \\
\text { confirmatory laboratory } \\
\text { samples }\end{array}$ \\
\hline
\end{tabular}


Table A.4-1

Decisions, Inputs, and General Strategies

(Page 2 of 2 )

\begin{tabular}{|c|c|c|c|c|}
\hline Decision & Input & Existing Data & Data Gap & Strategy \\
\hline \multirow{3}{*}{$\begin{array}{l}\text { Are potential } \\
\text { contaminants } \\
\text { migrating? }\end{array}$} & $\begin{array}{l}\text { Relative mobility of } \\
\text { potential } \\
\text { contaminant }\end{array}$ & $\begin{array}{c}\text { Potential contaminants associated with lavatory } \\
\text { facilities and associated janitorial activities; limited } \\
\text { migration in similar sites }\end{array}$ & Extent of COPCs & $\begin{array}{l}\text { Determine maximum } \\
\text { contamination extent as } \\
\text { discussed above }\end{array}$ \\
\hline & Meteorologic data & $\begin{array}{l}\text { Data on annual precipitation, evapotranspiration, } \\
\text { and weather available }\end{array}$ & None & $\begin{array}{l}\text { No site-specific } \\
\text { meteorological data will be } \\
\text { collected }\end{array}$ \\
\hline & $\begin{array}{l}\text { Geologic/hydrologic } \\
\text { data }\end{array}$ & $\begin{array}{l}\text { Assume near-surface investigation. General } \\
\text { geologic/hydrologic characteristics of site } \\
\text { available }\end{array}$ & None & $\begin{array}{l}\text { No specific geologic or } \\
\text { hydrologic data will be } \\
\text { collected for this site unless } \\
\text { drilling is required. General } \\
\text { soil characteristics will be } \\
\text { noted on sample collection log }\end{array}$ \\
\hline \multirow{3}{*}{$\begin{array}{l}\text { Data sufficient to } \\
\text { support closure } \\
\text { options? }\end{array}$} & No further action & $\begin{array}{c}\text { Historical evidence that COPCs released to the } \\
\text { environment at site; no further action may apply at } \\
\text { this site }\end{array}$ & $\begin{array}{l}\text { Presence, } \\
\text { concentration, and } \\
\text { extent of COPCs }\end{array}$ & $\begin{array}{c}\text { Insufficient evidence to } \\
\text { proceed without investigation. } \\
\text { Collect field and laboratory } \\
\text { samples; compare results to } \\
\text { PALs. If no COPCs above } \\
\text { PALs, prepare CADD/Closure } \\
\text { Report }\end{array}$ \\
\hline & Closure in place & Potential for VOCs and SVOCs & $\begin{array}{l}\text { Presence of } \\
\text { regulated COPCs; } \\
\text { concentrations } \\
\text { above PALs }\end{array}$ & $\begin{array}{l}\text { Collect field and laboratory } \\
\text { samples; compare results to } \\
\text { PALs. If no COPCs above } \\
\text { PALs, prepare CADD/Closure } \\
\text { Report; otherwise prepare } \\
\text { CADD }\end{array}$ \\
\hline & $\begin{array}{l}\text { Clean closure by } \\
\text { contaminant removal }\end{array}$ & Potential for VOCs and SVOCs & $\begin{array}{c}\text { Presence, } \\
\text { concentration, and } \\
\text { extent of COPCs; } \\
\text { volume of } \\
\text { contaminated } \\
\text { material above } \\
\text { PALs }\end{array}$ & $\begin{array}{l}\text { Collect field and laboratory } \\
\text { samples; compare results to } \\
\text { PALs. If no COPCs above } \\
\text { PALs, prepare CADD/Closure } \\
\text { Report; otherwise prepare } \\
\text { CADD }\end{array}$ \\
\hline
\end{tabular}




\section{A.5.0 Investigation Strategy}

Biased sampling will be conducted during the field investigation to confirm or refute the conceptual model for the site to assess the migration of the COPCs, and to determine if COPCs are present in concentrations exceeding the PALs for the site.

Sampling points will be selected within the leachfield, and at both ends of the septic tank (Figure A.5-1). Soil samples will be collected from the leachfield at 0.9 to $1.2 \mathrm{~m} \mathrm{(3.0} \mathrm{to} 4.0 \mathrm{ft}) \mathrm{bgs}$ and 2.1 to $2.4 \mathrm{~m}$ (7.0 to $8.0 \mathrm{ft}$ ) bgs. Soil samples will be collected from the inlet and outlet sides of the septic tank at 1.5 to $1.8 \mathrm{~m}(5.0$ to $6.0 \mathrm{ft}) \mathrm{bgs}$ and 2.7 to $3.0 \mathrm{~m}(9.0$ to $10.0 \mathrm{ft}) \mathrm{bgs}$. Field screening of the soil samples for radioactivity will be conducted. If field-screening levels are exceeded, additional samples will be collected for gamma-emitting radionuclide analysis as appropriate.

Soil samples will be collected by direct-push method. Regions exceeding the field screening levels or PALs would require a second stage of investigation through horizontal stepouts, trenching, or drilling to determine the extent of potential contaminants. 


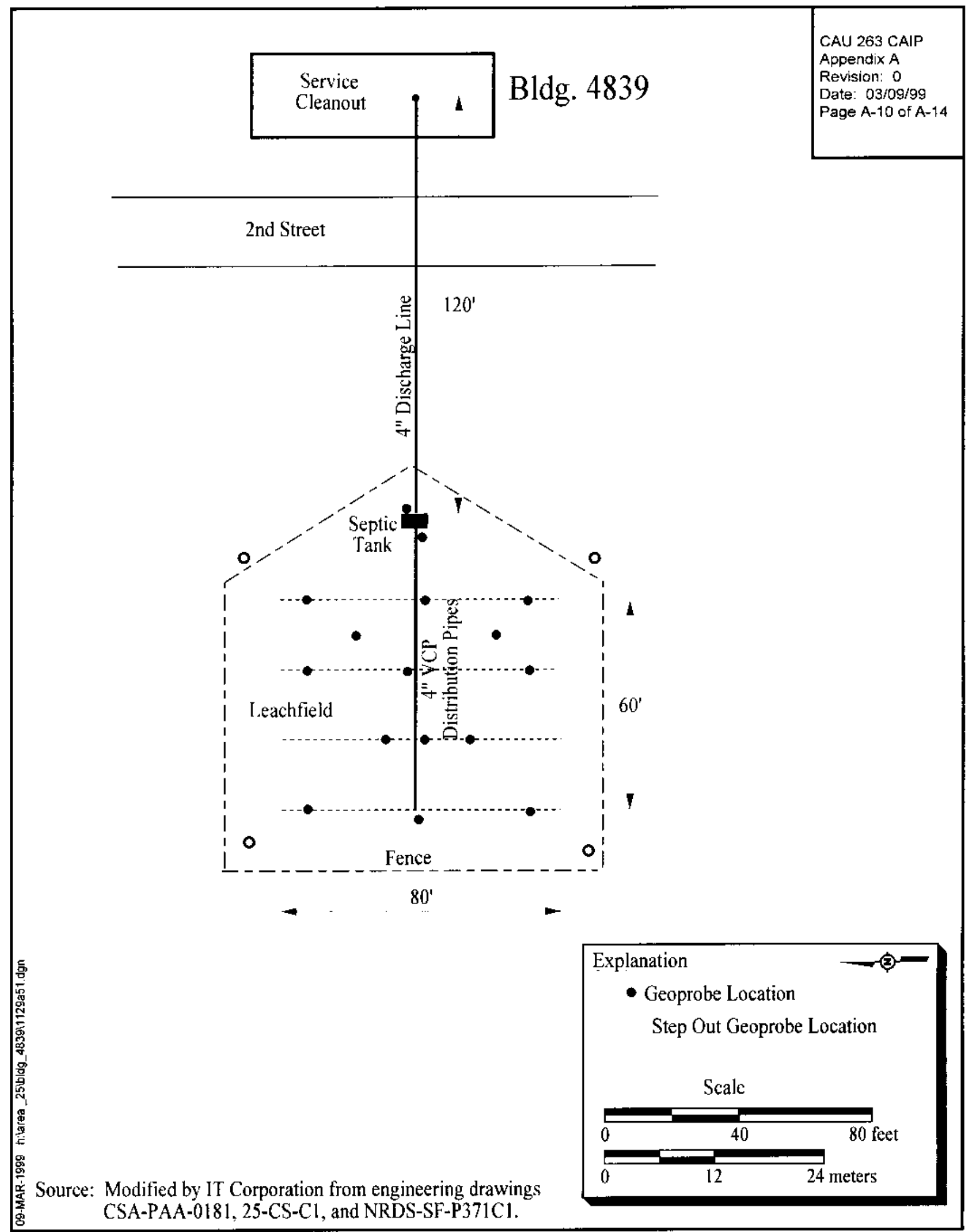

Figure A.5-1

CAU 263

Proposed Sampling Locations 


\section{A.6.0 Decision Rules}

The following decision rules are applicable to the CAS and will be used to guide the investigation and subsequent data evaluation.

- If, in the course of the investigation, either of the following occur, then the investigation will be halted and rescoped as necessary:

- The conceptual model fails to such a degree that rescoping is required.

- Sufficient data are collected to support evaluation of corrective actions.

- If field screening indicates the presence of COPCs above field-screening levels, then the investigation will continue to determine extent of these constituents until two, consecutive samples with field screening results below field screening levels are obtained. Samples will be collected for laboratory analysis at the prescribed intervals for the VOC and SVOC analysis. Additional samples may be collected at the discretion of the site supervisor.

- If laboratory results indicate the presence of VOCs and/or SVOCs above PALs, then a second stage of investigation will be conducted using trenching and/or borings to determine extent of contamination.

- If laboratory results indicated the presence of COPCs above PALs, then a CADD will be prepared.

- If no COPCs are identified above PALs, then a CADD/Closure Report will be prepared according to the outline agreed upon by NDEP and DOE/NV. This type of CADD incorporates the elements of the regular CADD and the corrective action plan and serves as the closure report for the site.

Table A.6-1 provides additional decision points and rules. 
Table A.6-1

CAS-Specific Decision Points and Rules

\begin{tabular}{|c|c|c|c|}
\hline $\begin{array}{l}\text { Investigation } \\
\text { Activity }\end{array}$ & Decision Point & $\begin{array}{l}\text { Decision } \\
\text { Result }\end{array}$ & Decision Rule \\
\hline \multirow{7}{*}{$\begin{array}{l}\text { Stage One } \\
\text { Investigation }\end{array}$} & \multirow{3}{*}{$\begin{array}{l}\text { Can leachfield be located } \\
\text { and sampled with } \\
\text { direct-push method? }\end{array}$} & Yes & Proceed with planned sampling strategy \\
\hline & & $\begin{array}{l}\text { Yes but in } \\
\text { different } \\
\text { location }\end{array}$ & Adjust investigation location based on evidence of actual leachfield location \\
\hline & & No & $\begin{array}{c}\text { Use other methods to locate and sample leachfield, such as trenching or drilling and } \\
\text { subsequent direct-push sampling }\end{array}$ \\
\hline & \multirow{2}{*}{$\begin{array}{l}\text { Do samples exceed } \\
\text { field-screening levels for } \\
\text { radioactivity }\end{array}$} & Yes & $\begin{array}{c}\text { Collect planned SVOC samples and additional VOC and/or radionuclide samples until } \\
\text { samples below field-screening levels are recovered; additional samples will be analyzed } \\
\text { for SVOCs and constituents exceeding field-screening levels }\end{array}$ \\
\hline & & No & Collect SVOC and VOC samples as planned \\
\hline & \multirow{2}{*}{$\begin{array}{l}\text { Do Stage One samples } \\
\text { exceed PALs for VOCs } \\
\text { and/or SVOCs }\end{array}$} & Yes & $\begin{array}{l}\text { Conduct additional investigation using video survey of collection system and Stage Two } \\
\text { sampling using trenching or drilling to establish contamination extent }\end{array}$ \\
\hline & & No & Investigation complete \\
\hline \multirow{2}{*}{$\begin{array}{l}\text { Stage } 2 \\
\text { Investigation }\end{array}$} & \multirow{2}{*}{$\begin{array}{l}\text { Is collection system } \\
\text { intact? }\end{array}$} & Yes & Collect additional samples from soils associated with leachfield or septic tank only \\
\hline & & No & $\begin{array}{l}\text { Collect additional samples from soils associated with leachfield or septic tank and from } \\
\text { collection-system breaches }\end{array}$ \\
\hline
\end{tabular}




\section{A.7.0 Decision Error}

Biased sampling will be conducted on near-surface samples at CAS 25-05-04. Biased sampling is appropriate because the locations are known or can be reasonably assumed. Table A.6-1 describes actions if the location cannot be identified.

The sampling strategy targets the worst-case contamination by sampling the leachfield system especially at points with highest potential for contamination. This will ensure that the extent of the contamination has been adequately located and identified. Two consecutive samples below field screening levels will be obtained from the sample locations to define the lower limit of the affected soils, and these field screening results will be confirmed by off-site laboratory analysis. 


\section{A.8.0 References}

DOE, see U.S. Department of Energy.

DOE/NV, see U.S. Department of Energy, Nevada Operations Office.

U.S. Department of Energy, Nevada Operations Office. 1996a. Final Environmental Impact Statement for the Nevada Test Site and Off-Site Locations in the State of Nevada, DOE/EIS 0243, Las Vegas, NV.

U.S. Department of Energy, Nevada Operations Office. 1996b. Industrial Sites Quality Assurance Project Plan, DOE/NV--372. Las Vegas, NV.

U.S. Department of Energy, Nevada Operations Office. 1998. Work Plan for Leachfield Corrective Action Units: Nevada Test Site and Tonopah Test Range, Nevada, DOE/NV--514.

Las Vegas, NV. 


\section{Appendix B}

\section{Project Organization}




\section{B.1.0 Project Management}

The DOE/NV Project Manager is Janet-Appenzeller Wing. She can be contacted by telephone at (702) 295-0461.

The identification of the project Health and Safety Officer and the Quality Assurance Officer can be found in the DOE/NV Field Management Plan for the individual CAUs. However, personnel are subject to change, and it is suggested that the Project Manager be contacted for further information. The Task Manager will be identified in the FFACO Biweekly Activity Report prior to the start of field activities. 


\section{Appendix C}

\section{Engineering Drawings of CAU 263}




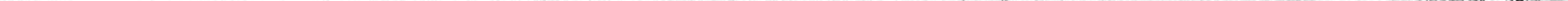




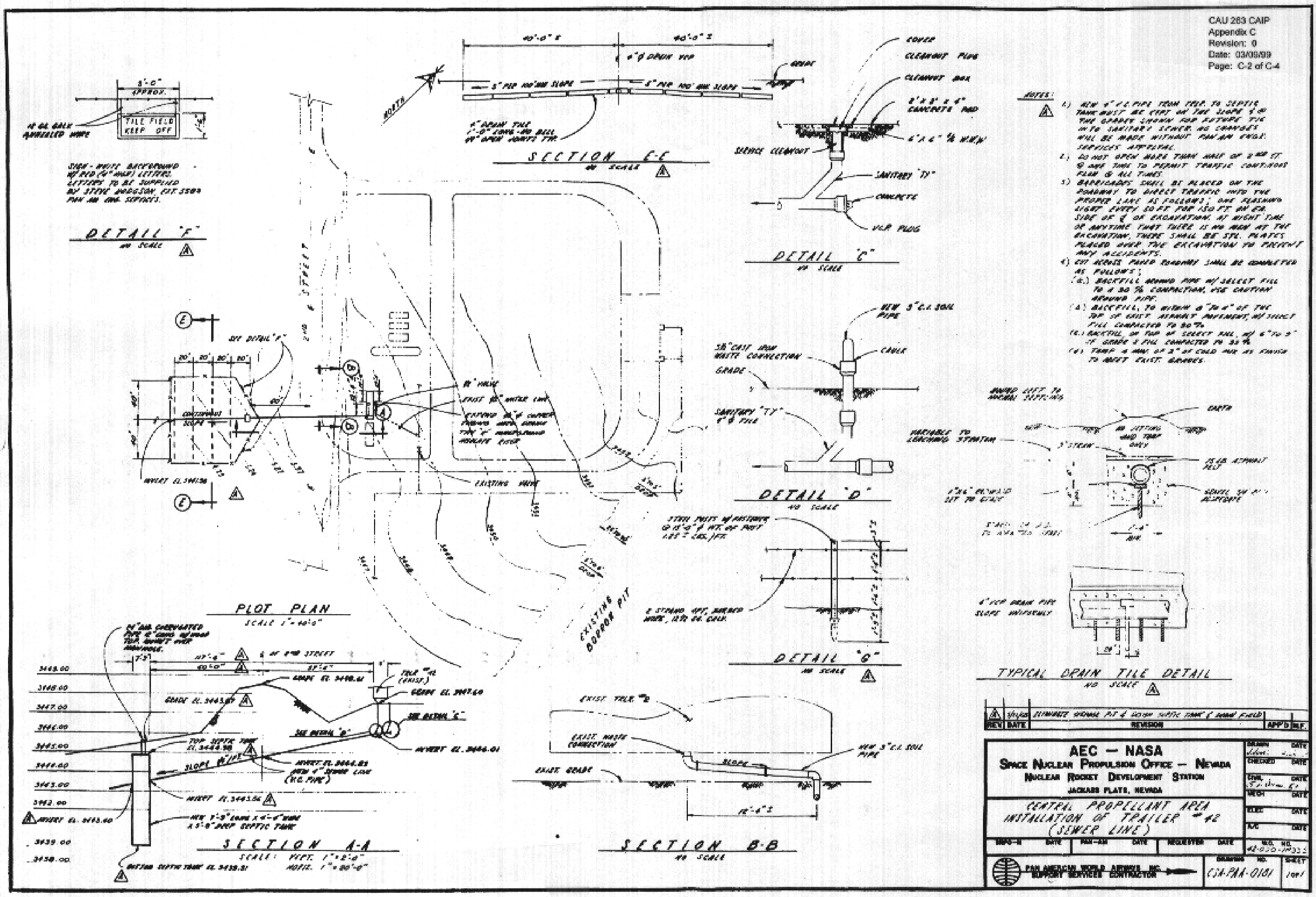




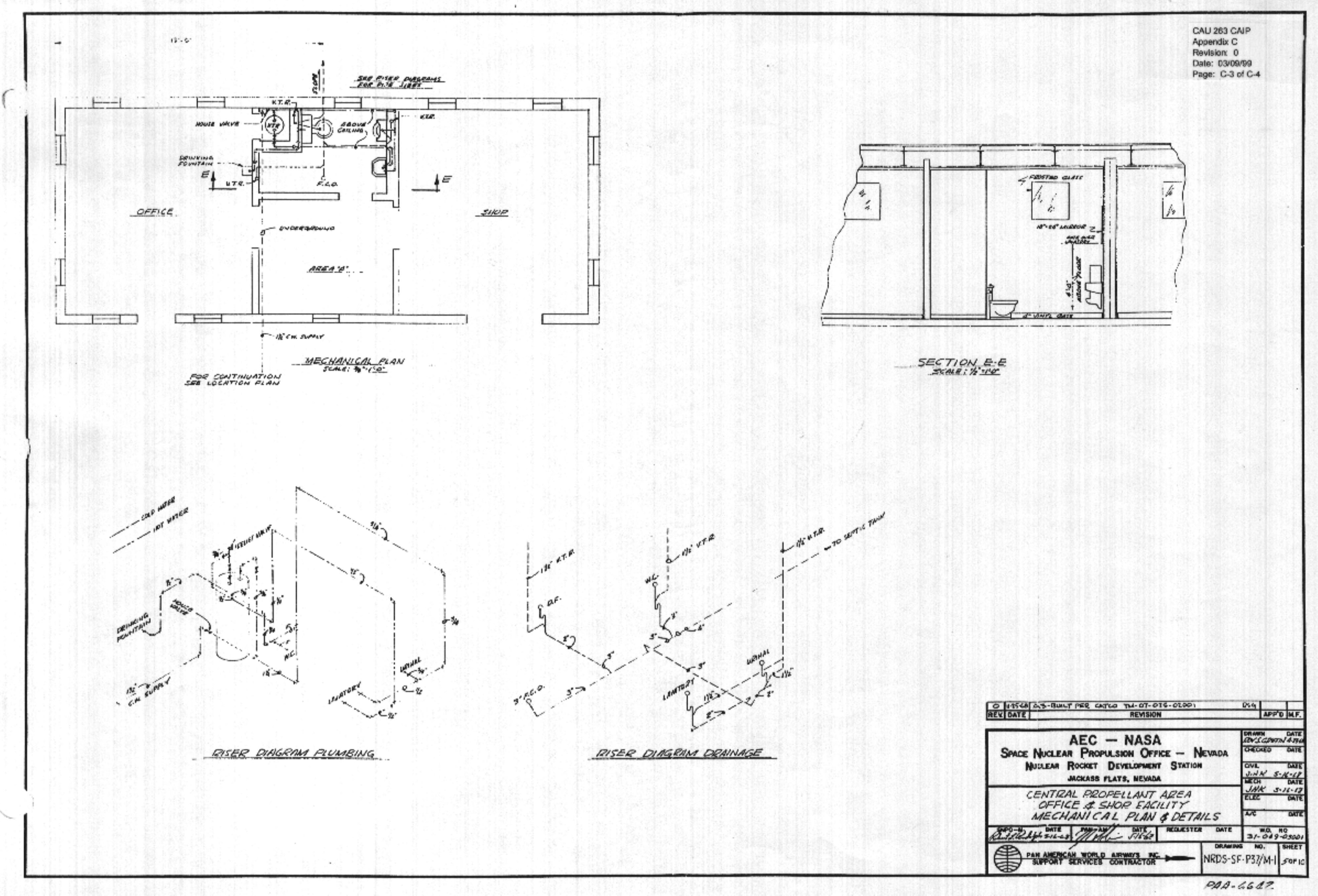




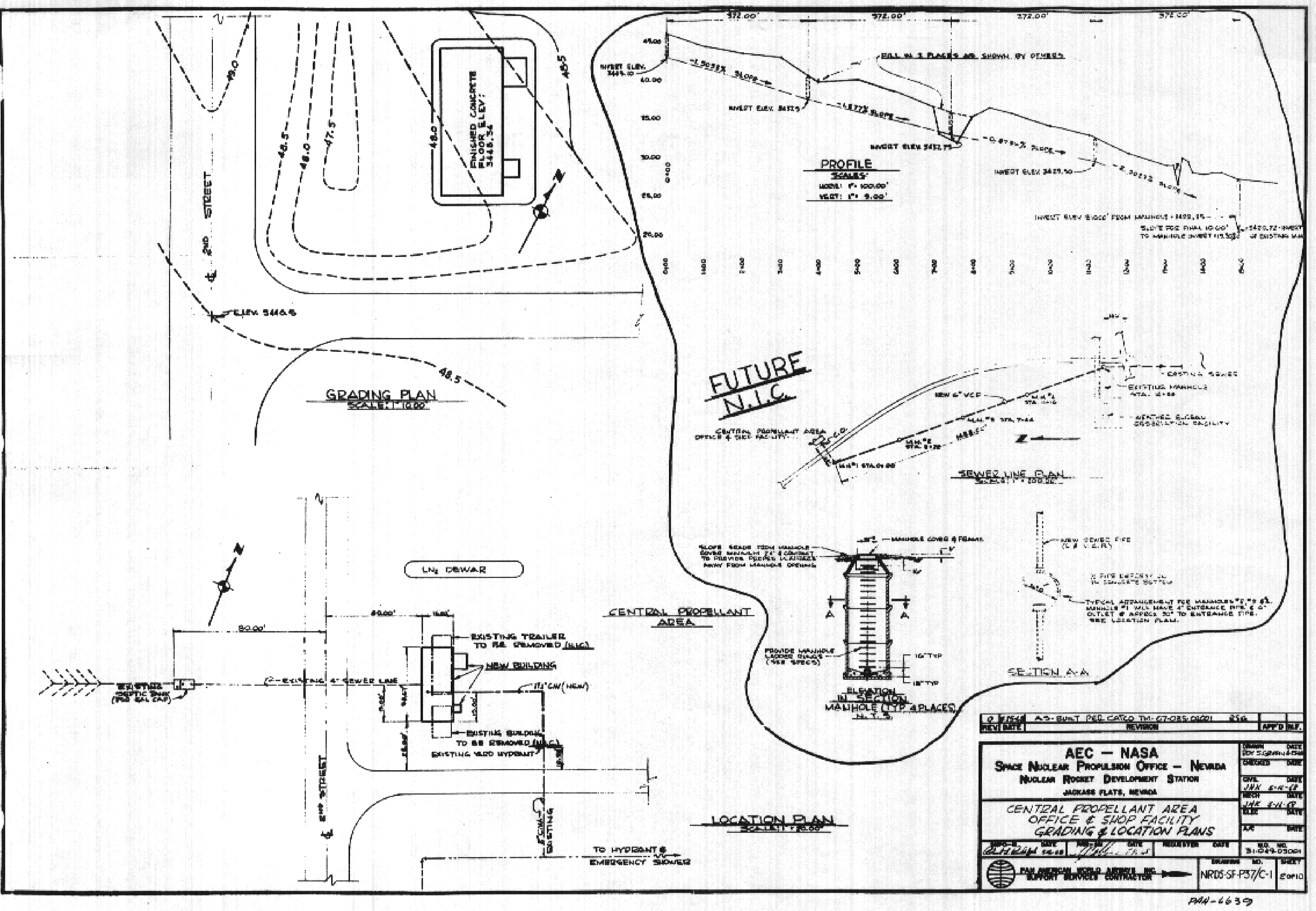




\section{Appendix D}

\section{NDEP Comment Review Sheets}




\section{NEVADA ENVIRONMENTAL RESTORATION PROJECT DOCUMENT REVIEW SHEET}

\section{(Page 1 of 1)}

\begin{tabular}{|c|c|c|c|c|c|}
\hline \multicolumn{4}{|c|}{$\begin{array}{l}\text { 1. Document Title/Number: Draft Corrective Action Investigation Plan for CAU 263, Area } 25 \text { Building } 4839 \\
\text { Leachfield, Nevada Test Site }\end{array}$} & \multicolumn{2}{|c|}{ 2. Document Date: December, 1998} \\
\hline \multicolumn{4}{|c|}{ 3. Revision Number: Draft Rev. 0} & \multicolumn{2}{|c|}{ 4. Originator/Organization: IT Corporation } \\
\hline \multicolumn{4}{|c|}{ 5. Responsible DOE/NV ERP Subproject Mgr.: Clayton Barrow } & \multicolumn{2}{|c|}{ 6. Date Comments Due: 02/10/99 } \\
\hline \multicolumn{6}{|c|}{ 7. Review Criteria: Full } \\
\hline \multicolumn{4}{|c|}{ 8. Reviewer/Organization/Phone No.: Gregory Raab - NDEP } & \multicolumn{2}{|l|}{ 9. Reviewer's Signature: } \\
\hline $\begin{array}{l}\text { 10. Comment } \\
\text { Number/ } \\
\text { Location }\end{array}$ & 11. Type* & 12. Comment & \multicolumn{2}{|c|}{ 13. Comment Response } & 14. Accept \\
\hline $\begin{array}{l}\text { 1. Page } 9 \text { of } 23 \text {, } \\
\text { Section } 3.2 \text {, } \\
\text { Contaminants of } \\
\text { Potential } \\
\text { Concern }\end{array}$ & M & $\begin{array}{l}\text { There is no listing of the site specific COPC as agreed upon in the } \\
\text { DQO meetings. A general reference to all COPCs listed in } \\
\text { Table } 3.1 \text { in the Leachfield Work Plan is unacceptable. This section } \\
\text { should list the COPCs which are specific to this site. }\end{array}$ & \multicolumn{2}{|c|}{ A bulleted list of COPCs was added to Section 3.2. } & Yes \\
\hline $\begin{array}{l}\text { 2. Page } 15 \text { of } \\
\text { 23, 2nd Para., } \\
4^{\text {th }}, 5^{\text {th }} \text {, and } 6^{\text {th }} \\
\text { Sentences }\end{array}$ & M & $\begin{array}{l}\text { In general, the first portion of soil will be retained for the analytes } \\
\text { most sensitive to volatilization (VOCs). The next portion will be } \\
\text { retained for field screening of SVOCs. The third portion will be } \\
\text { retained for other analytes, such as the radiological components. }\end{array}$ & \multicolumn{2}{|c|}{ Change made. } & Yes \\
\hline
\end{tabular}

${ }^{a}$ Comment Types: $M=$ Mandatory, $S=$ Suggested

Return Document Review Sheets to DOE/NV Environmental Restoration Division, Attn: QAC, M/S 505. 


\section{Distribution}

*Provide copy in distribution of Rev. 0 and subsequent revisions if applicable. Copies of only the NDEP-approved document will be distributed to others.

Paul J. Liebendorfer

State of Nevada

Bureau of Federal Facilities

Division of Environmental Protection

333 W. Nye Lane, Room 138

Carson City, NV 89706-0851

Michael McKinnon

State of Nevada

Bureau of Federal Facilities

Division of Environmental Protection

555 E. Washington, Suite 4300

Las Vegas, NV 89101

Sabrina Lawrence

Environmental Restoration Division

DOE/Nevada Operations Office

P.O. Box 98518, M/S 505

Las Vegas, NV 89193-8518

Janet Appenzeller-Wing

Environmental Restoration Division

DOE/Nevada Operations Office

P.O. Box 98518, M/S 505

Las Vegas, NV 89193-8518

Clayton Barrow

Environmental Restoration Division

DOE/Nevada Operations Office

P.O. Box 98518, M/S 505

Las Vegas, NV 89193-8518

Steve Nacht

Bechtel Nevada

P.O. Box 98521, M/S NTS306

Las Vegas, NV 89193-8521
2 (Controlled)* $^{*}$

1 (Controlled)*

1 (Controlled)*

1 (Uncontrolled)*

1 (Uncontrolled)*

1 (Uncontrolled)* 
Jerry Bonn

Bechtel Nevada

P.O. Box 98521, M/S NTS306

Las Vegas, NV 89193-8521

IT Corporation Central Files

P.O. Box 93838

Las Vegas, NV 89193

Candice Fillmore

SAIC

P.O. Box 93838

Las Vegas, NV 89193

Mary Todd

SAIC

P.O. Box 93838

Las Vegas, NV 89193

Technical Information Resource Center

DOE/Nevada Operations Office

P.O. Box 98518, M/S 505

Las Vegas, NV 89193-8518

U.S. Department of Energy

Office of Scientific and Technical Information

P.O. Box 62

Oak Ridge, TN 37831

Manager Southern Nevada FFACO

Public Reading Room

P.O. Box 98521, M/S NLV040

Las Vegas, NV 89193-8521

Manager Northern Nevada FFACO

Public Reading Room

c/o Rosa Silver

IT Corporation

P.O. Box 93838

Las Vegas, NV 89193
1 (Uncontrolled)*

1 (Uncontrolled)*

1 (Controlled)*

1 (Uncontrolled)* $^{*}$

1 (Uncontrolled)

1 (Uncontrolled, electronic copy)

1 (Controlled)

1 (Uncontrolled)

1 (Uncontrolled) 
Rosa Silver

IT Corporation

P.O. Box 93838

Las Vegas, NV 89193 